\title{
On Lunar Periodicity in Reproduction of Pecten opercularis near Plymouth in 1927-28.
}

By

\author{
C. Amirthalingam, B.Sc.
}

With 5 Figures in the Text.

\section{CONTENTS.}

PAGE

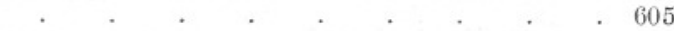

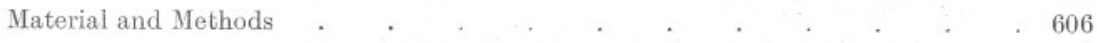

The size of the specimens . . . . . . . . . . . . . . . . . 606

Remarks on the gonad . . . . . . . . . . . . . . . . . . . 608

The variation in the condition of the ovary and of the testis $\quad . \quad$. $\quad . \quad 608$

The variation in the colour of the ovary and of the testis . . . . . . . 609

The relative size of the ovary and of the testis . . . . . . . . . . 610

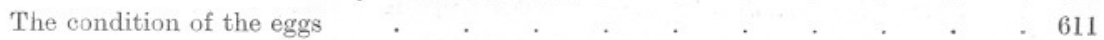

The presence or absence of ripe sperms . . . . . . . . . . . . 612

Criteria of ripeness and unripeness in males and females defined . . . . . 613

The periodicity in the occurrence of the ripe generative products $\quad . \quad$. $\quad$. 614

The gut contents of queens . . . . . . . . . . . . . . . . . $\quad .618$

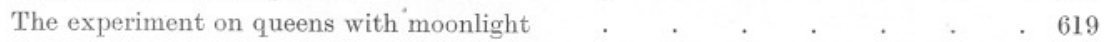

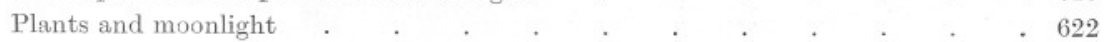

The lunar periodicity of reproduction in animals already described . . . . 623

Discussion on the probable causes of periodicity in reproduction $\quad . \quad$. 624

Conclusions regarding the phenomenon recorded . . . . . . . . . . $\quad .626$

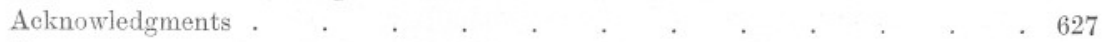

Summary . . . . . . . . . . . . . . . . . . . . . . . 627

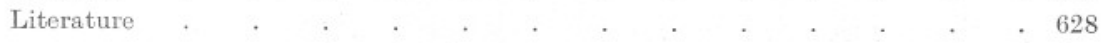

\section{INTRODUCTION.}

THE belief that the moon has an effect on the life of animals and plants is found in the literature of ancient Greece and Rome, and is held to-day among the fishing population in the East as well as in the West. In Plymouth there is a general belief that queens (Pecten opercularis) get "full" and "empty" with the waxing and waning of the moon. To test the truth of this, systematic examinations of the gonads of $P$. opercularis were made, and the results are embodied in the following pages.

NEW SERIES.-VOL. XV. NO. 2. APRIL, 1928. 


\section{Material and Methods.}

The material was obtained from the trawling grounds within an area of 25-30 miles radius of Plymouth, especially from the neighbourhood of Eddystone and of Mewstone, brought in either by the Salpa of the Marine Biological Association or by the commercial trawlers which came into port in the mornings. In both cases, the samples were kept under circulation and examined on the same day or the day following.

The right valve shell with the right mantle and the right gills was cut off and the following observations were made :-

(a) the size of the shell,

(b) the condition of the ovary and of the testis,

(c) the colour of the ovary and of the testis,

(d) the relative size of the ovary and of the testis,

(e) the condition of the eggs,

and $(f)$ the presence or absence of ripe sperms.

The animals were then preserved in $5 \%$ formalin. The ovary of the preserved specimens was cut transversely at the point of the junction with the testis, and the major and the minor axes of the exposed face were measured. For sectioning, the specimens were fixed in Bouin's fluid and stained with iron hæmotoxylin and eosin by the usual method.

\section{The Size of the Specimens.}

From Table I (p. 607) it is clear that a large proportion of the individuals from the Eddystone and the trawling grounds was between 40 and $60 \mathrm{~mm}$. in shell-length, whereas those from the Mewstone grounds were mainly of a smaller size ranging between $30-40 \mathrm{~mm}$.

Although no definite information is available on the rate of growth of Pecten opercularis, yet by examining the shells it is possible to state the probable age of the animal by the vaguely-defined annular rings. The first year's growth can be seen clearly, especially in the right valve shell of small specimens, by the occurrence of a smooth surface in the furrows between the rays, and varies between $20-25 \mathrm{~mm}$. in length. In some shells,

\section{NOTES ON TABLE I.}

The samples marked "Eddystone gds." were trawled from a region 10 miles S. $\times$ S.E. of Eddystone Lighthouse, and those marked "Mewstone gds." 4 miles S. of Mewstone; both lots were brought in by s.s. Salpa of the M.B.A. The samples marked "Trawling gds." were obtained from the commercial trawlers working within an area of 25-30 miles of Plymouth. The same remarks apply to Table II.

[I am indebted to Capt. V. Lord of s.s. Salpa for the above information.]

The size of the specimens recorded was determined either by cardboard rings of 30 , 40,50 , and $60 \mathrm{~mm}$. diameter, or by direct measurement of the maximum length of the shell parallel to the hinge and the maximum height at right-angles to the hinge. 


\section{TABLE I.}

The Results of' the Examination of the Samples for the Size of Individuals from Fishing Grounds within a Radius of 25-30 miles of Plymouth.

\begin{tabular}{|c|c|c|c|c|c|c|c|c|c|c|c|}
\hline & $\begin{array}{l}\text { Date. } \\
1927\end{array}$ & Locality. & $\begin{array}{c}\text { Total } \\
\text { No. }\end{array}$ & $\begin{array}{c}\text { Shell } \\
n \\
\text { Ring } \\
\text { No. }\end{array}$ & $\begin{array}{l}30-40 \\
\text { im. } \\
\text { No. } 1 \\
\%\end{array}$ & $\begin{array}{c}\text { Shell } \\
\text { m } \\
\text { Ring } \\
\text { No. }\end{array}$ & $\begin{array}{l}0-50 \\
\text { m. } \\
\text { No. } 2 \\
\%\end{array}$ & $\begin{array}{c}\text { Shell } \\
\mathrm{m} \\
\text { Ring } \\
\text { No. }\end{array}$ & $\begin{array}{l}0-60 \\
\text { n. } \\
\text { No. } 3 \\
\%\end{array}$ & $\begin{array}{r}\text { Shell } \\
\text { m. } \\
\text { Ring } \\
\text { No. }\end{array}$ & $\begin{array}{l}60-70 \\
\text { m. } \\
\text { No. } 4 \\
\frac{1}{6}\end{array}$ \\
\hline 9 th . & March & Trawling gds. & 180 & - & - & 66 & $36 \cdot 6$ & 100 & $55 \cdot 6$ & 14 & $7 \cdot 8$ \\
\hline 13 th & , & , & 170 & 2 & $1 \cdot 1$ & 78 & $43 \cdot 8$ & 94 & $52 \cdot 9$ & 4 & $2 \cdot 2$ \\
\hline 18 th & ," & ," & 149 & - & - & 32 & $21 \cdot 5$ & 99 . & 66.5 & 18 & $12 \cdot 0$ \\
\hline $23 \mathrm{rd}$ & ," & ," & 74 & 2 & $2 \cdot 7$ & 24 & $32 \cdot 4$ & 39 & $52 \cdot 6$ & 9 & $12 \cdot 3$ \\
\hline 29 th & , & , & 100 & - & - & 5 & $5 \cdot 0$ & 82 & $82 \cdot 0$ & 13 & $13 \cdot 0$ \\
\hline 7 th & April & , & 76 & - & - & 40 & $52 \cdot 6$ & 36 & $47 \cdot 4$ & - & - \\
\hline 15 th & $"$ & , & 104 & - & - & 29 & $27 \cdot 9$ & 72 & $69 \cdot 2$ & 3 & $2 \cdot 9$ \\
\hline $22 \mathrm{nd}$ & , & , & 109 & - & - & 2 & $1 \cdot 8$ & 105 & $96 \cdot 3$ & 2 & $1 \cdot 8$ \\
\hline 6 th 1 & May & Eddystone gds. & 100 & - & - & 70 & $70 \cdot 0$ & 29 & $29 \cdot 0$ & 1 & 1.0 \\
\hline 13 th &, & , & 100 & - & - & 72 & $72 \cdot 0$ & 27 & $27 \cdot 0$ & 1 & 1.0 \\
\hline 18th & , & , & 100 & 1 & $1 \cdot 0$ & 64 & $64 \cdot 0$ & 33 & $33 \cdot 0$ & 2 & $2 \cdot 0$ \\
\hline 26 th & , & , & 125 & 2 & $1 \cdot 6$ & 86 & $68 \cdot 8$ & 34 & $27 \cdot 2$ & 3 & $2 \cdot 4$ \\
\hline lst J & June & Trawling gds. & 100 & - & - & 41 & $41 \cdot 0$ & 56 & $56 \cdot 0$ & 3 & $3 \cdot 0$ \\
\hline 8 th & , & Eddystone gds. & 100 & - & - & 62 & $62 \cdot 0$ & 38 & $38 \cdot 0$ & - & - \\
\hline 15 th & , & Trawling gds. & 100 & - & - & 21 & $21 \cdot 0$ & 67 & $67 \cdot 0$ & 12 & $12 \cdot 0$ \\
\hline 17 th & , &, & 100 & 1 & $1 \cdot 0$ & 44 & $44 \cdot 0$ & 53 & $53 \cdot 0$ & 2 & $2 \cdot 0$ \\
\hline 2lst &, & ," & 125 & - & - & 66 & $52 \cdot 8$ & 58 & $46 \cdot 4$ & 1 & 0.8 \\
\hline lst J & July & Mewstone gds. & 100 & 75 & $75 \cdot 0$ & 22 & $22 \cdot 0$ & 3 & $3 \cdot 0$ & - & - \\
\hline 6 th & , & , & 95 & 70 & $73 \cdot 8$ & 22 & $23 \cdot 1$ & 3 & $3 \cdot 1$ & - & - \\
\hline 13 th & , & Eddystone gds. & 100 & - & - & 44 & $44 \cdot 0$ & 52 & $52 \cdot 0$ & 4 & $4 \cdot 0$ \\
\hline 2lst & , & Trawling gds. & 144 & 1 & $0 \cdot 7$ & 28 & $19 \cdot 4$ & 115 & $79 \cdot 9$ & - & - \\
\hline 26th & , & , & 119 & - & - & 6 & $5 \cdot 5$ & 109 & $91 \cdot 2$ & 4 & $3 \cdot 3$ \\
\hline 29 th & ", & Mewstone gds. & 86 & 57 & $66 \cdot 3$ & 29 & $33 \cdot 7$ & - & - & - & - \\
\hline 5 th A & ugust & , & 135 & 52 & $38 \cdot 5$ & 77 & $57 \cdot 1$ & 6 & $4 \cdot 4$ & - & - \\
\hline 11 th & , & , & 100 & 65 & $65 \cdot 0$ & 33 & $33 \cdot 0$ & 2 & $2 \cdot 0$ & - & - \\
\hline 16 th & , & ,, & 62 & 33 & $53 \cdot 2$ & 27 & $43 \cdot 6$ & 2 & $3 \cdot 2$ & - & - \\
\hline $17 \mathrm{th}$ & , & Eddystone gds. & 100 & 1 & $1 \cdot 0$ & 32 & $32 \cdot 0$ & 66 & $66 \cdot 0$ & I & I 0 \\
\hline $23 \mathrm{rd}$ & , & , & 35 & - & - & 30 & $85 \cdot 8$ & 4 & $1 \cdot 14$ & 1 & $2-8$ \\
\hline 30 th & , & Mewstone gds. & 164 & 92 & $56 \cdot 2$ & 67 & $40 \cdot 8$ & 5 & $3 \cdot 0$ & - & \\
\hline $9 \operatorname{th} \mathrm{S}$ & September & Trawling gds. & 165 & - & - & 34 & $20 \cdot 7$ & 130 & $78 \cdot 7$ & 1 & 0.6 \\
\hline 14th & , & stone gds. & 180 & 4 & $2 \cdot 2$ & 31 & $17 \cdot 4$ & 142 & $78 \cdot 8$ & 3 & $1 \cdot 6$ \\
\hline 19 th & , & tone gds. & 37 & 23 & $62 \cdot 2$ & 13 & $35 \cdot 1$ & 1 & $2 \cdot 7$ & - & - \\
\hline 27 th &, & Trawling gds. & 170 & 2 & $1 \cdot 2$ & 56 & $32 \cdot 8$ & 112 & $66 \cdot 0$ & - & - \\
\hline 4 th ( & October & , & 212 & 7 & $3 \cdot 3$ & 72 & $33 \cdot 7$ & 130 & $61 \cdot 6$ & 3 & $1 \cdot 4$ \\
\hline 9 th & ", & , & 200 & 4 & $2 \cdot 0$ & 51 & $25 \cdot 5$ & 142 & $71 \cdot 0$ & 3 & $1 \cdot 5$ \\
\hline 11 th & ,", & , & 200 & 10 & $5 \cdot 0$ & 69 & $34 \cdot 5$ & 119 & $59 \cdot 5$ & 2 & 1.0 \\
\hline 19th & ," & ", & 200 & 7 & $3 \cdot 5$ & 80 & $40 \cdot 0$ & 112 & $56 \cdot 0$ & 1 & 0.5 \\
\hline 24th & , , & , & 100 & 1 & $1 \cdot 0$ & 24 & $24 \cdot 0$ & 69 & $69 \cdot 0$ & 6 & $6 \cdot 0$ \\
\hline lst $\mathrm{N}$ & November & , & 120 & - & - & 32 & $26 \cdot 6$ & 88 & $73 \cdot 4$ & - & - \\
\hline 8 th & , & ", & 100 & 3 & $3 \cdot 0$ & 18 & 18.0 & 74 & $74 \cdot 0$ & 5 & $5 \cdot 0$ \\
\hline 15 th & ", & , & 130 & - & - & 20 & $15 \cdot 4$ & 103 & $79 \cdot 2$ & 7 & $5 \cdot 4$ \\
\hline $22 n d$ & $"$ & , & 100 & - & - & 15 & $15 \cdot 0$ & 80 & $80 \cdot 0$ & 5 & $5 \cdot 0$ \\
\hline 2nd $]$ & December & ", & 100 & - & - & 25 & $25 \cdot 0$ & 68 & $68 \cdot 0$ & 7 & $7 \cdot 0$ \\
\hline 9 th & , & , & 100 & - & - & 6 & $6 \cdot 0$ & 91 & $91 \cdot 0$ & 3 & $3 \cdot 0$ \\
\hline 13 th & ", & ", & 100 & - & - & 12 & $12 \cdot 0$ & 81 & $81 \cdot 0$ & 7 & $7 \cdot 0$ \\
\hline $22 \mathrm{nd}$ & , &, & 100 & - & - & 14 & $14 \cdot 0$ & 80 & $80 \cdot 0$ & 6 & $6 \cdot 0$ \\
\hline $\begin{array}{l}30 \text { th } \\
192\end{array}$ & 8." & Eddystone gds. & 100 & - & - & 8 & $8 \cdot 0$ & 88 & $88 \cdot 0$ & 4 & $4 \cdot 0$ \\
\hline 4 th J & January & Trawling gds. & 100 & - & - & 8. & $8 \cdot 0$ & 83 & $83 \cdot 0$ & 9 & $9 \cdot 0$ \\
\hline 10th & , & ", & 100 & - & - & 1 & $1 \cdot 0$ & 88 & $88 \cdot 0$ & 11 & $11 \cdot 0$ \\
\hline 18th & , & , & 100 & - & - & 2 & $2 \cdot 0$ & 87 & $87 \cdot 0$ & 11 & $11 \cdot 0$ \\
\hline 31 st &, & , & 10 & 3 & $3 \cdot 0$ & 16 & $16 \cdot 0$ & 80 & $80 \cdot 0$ & 1 & $1 \cdot 0$ \\
\hline 3rd I & Februa &, & 100 & 1 & $1 \cdot 0$ & 8 & $8 \cdot 0$ & 88 & $88 \cdot 0$ & 3 & $3 \cdot 0$ \\
\hline 7 th & $"$ & , & 100 & 1 & $1 \cdot 0$ & 15 & $15 \cdot 0$ & 82 & $82 \cdot 0$ & 2 & $2 \cdot 0$ \\
\hline 15th & $"$ & , & 95 & - & - & 11 & $11 \cdot 5$ & 81 & $85 \cdot 3$ & 3 & $3 \cdot 2$ \\
\hline
\end{tabular}


either by the variation in the colour or by the thickness of the shell, two other rings can be seen. One occurring at a distance of about $40 \mathrm{~mm}$. and the other at about $60 \mathrm{~mm}$. from the umbo. It is from these observations the following suggestion is made that, in the second year, an additional shell-length of $20-25 \mathrm{~mm}$. is secreted with the furrows now becoming roughened and continuing to be so with the further growth of the shell; in the third year, the shell reaching a length of $40-60 \mathrm{~mm}$.; in the fourth year, more than $60 \mathrm{~mm}$. By this method of reckoning it can be stated that the specimens from the Channel were 3-4 years old and those from the Mewstone 2-3 years old. Yet the periodicity of spawning (p. 614) is not affected by the age of the individuals.

\section{Remarks on the Gonad.}

The hermaphrodite organ is a tongue-like process situated ventrally and posteriorly to the rudimentary foot (Dakin, 8, Fig. 1, Pl. 2). It forms a prominent mass stretching to the middle surface of the adductor muscle posteriorly, and to the under surface of the digestive gland close behind the mouth anteriorly. Slightly constricted behind the foot, it gradually increases in size until it attains its greatest breadth nearly opposite the posterior end of the organ of Bojanus, where the seminiferous part abuts against the ovigerous portion. From this point it tapers to a blunted end. The posterior part is the ovary and the anterior region the testis.

\section{The Variation in the Condition of the Ovary and of THE Testis.}

(a) The spawned condition of the gonad=" spent."

After the discharge of the generative products or before the products have developed, both the ovary and the testis are in a collapsed condition, i.e. the lateral walls of the organ lie close to each other and the organ does not extend posteriorly beyond the point of attachment to the adductor muscle. At this stage, a transverse section at the junction of the ovary and of the testis reveals an ellipsoid shape whose minor axis is about half or less than half that of the major axis. This condition was observed in most of the individuals collected in September, October, and November, and in the spawned ones during the breeding season-January to June inclusive. This stage in the history of the development of the gonad is indicated in the records (p. 633) as "spent."

(b) The developing condition of the gonad=" Half-full."

As development begins, the walls of the organ become stretched in all directions ; the anterior end being fixed, the tendency of the organ is to elongate posteriorly beyond the attached point, passing from a collapsed 
form to a knee-shaped form, and to expand laterally into the mantle cavity. In transverse section the gonad has an elliptical shape whose minor and major axes tend to become equal ; an intermediate stage when the minor axis is not more than two-thirds that of the major axis is noted as "Half-full" in the records (p. 633). This condition was observed in most of the specimens obtained between the third quarter and the first quarter of the moon during the breeding season and in July, August and December.

(c) The ripening or the ripe condition of the gonad=" Full."

In the mature condition, the reproductive organ is at its largest and is firm in consistency as if the contents were pressing against the walls laterally, so that a transverse section of the organ now reveals a phase which is more circular than elliptical. This stage when the minor axis is more than two-thirds that of the major axis is indicated as "Full " in the records (p. 633). The maximum number of individuals with ripening or ripe gonad was found in samples examined between the first quarter and the full moon during the breeding season.

\section{The Variation in the Colour of the Ovary and of the Testis.}

In the collapsed or undeveloped condition, the ovary exhibits a light brown colour (Klincksieck et Valette, 31, Shade No. 117, e.g. Specimen No. 67 , p. 633 of this paper). When the tissues become active the colour changes with the increase in size, first assuming a reddish tinge (ibid., Shade No. 91, e.g. Specimen No. 35, p. 633) and then passing to bright scarlet (ibid., Shade No. 81, e.g. Specimen No. 46, p. 633) or rich vermilion (ibid., Shade No. 76, e.g. Specimen No. 25, p. 633), through a pale red phase (ibid., Shade No. 86, e.g. Specimen No. 2, p. 633). A few individuals, however, were observed to possess a white ovary in developing and in mature conditions.

The spent or resting testis is transparent and colourless (e.g. Specimen No. 88, p. 634). As spermatogenesis starts, the organ becomes opaque and finally attains an opalescent (ibid., Shade No. 0171, e.g. Specimen No. 1, p. 633) or a creamy colour (e.g. Specimen No. 15, p. 633). The creamy colour and the "full " condition of the testis is a sure indication of the mature products.

An additional feature of interest in connection with the pigmentation of the gonad has been observed in some individuals of $P$. opercularis from Mewstone grounds. In a small percentage of thin-shelled individuals, it was noticed towards the beginning of July that black pigment had been laid down on the ventral margin of the gonad at the junction of the ovary and of the testis. It seems probable that the pigment may have been 
produced as a reaction to the penetration of the thin shell by actinic rays. A similar phenomenon had been observed in Ostrea edulis $(48$, p. 951) in which black pigment is laid down on the left side in the epithelium covering the visceral mass and also abundantly on the edges of the mantle; in Cucumaria saxicola, whose skin becomes generally dusty black after prolonged exposure to light; and in C. normani, in which the tentacles become black when exposed to light.

\section{The Relative Size of the Ovary and of the Testis.}

From the records (p. 633) it is clear that the absolute length of the full gonad is related directly to the size of the shell, i.e. the bigger the shell the longer the gonad, and vice versa.

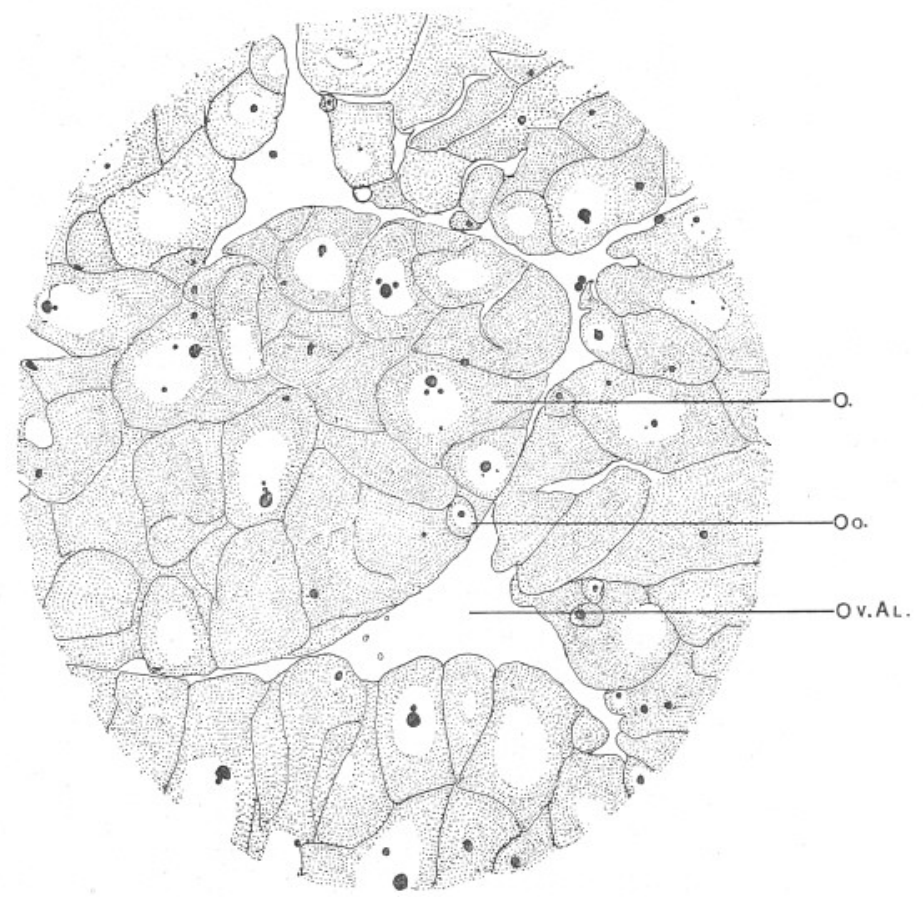

FIG. 1. A drawing (made with 2 eye-piece and $\frac{1}{6}$ objective. Leitz.) of a section through a ripe ovary of Pecten opercularis.

$0 .=$ nearly ripe or ripe egg. Oo.=young oocytes.

Ov. AL. $=$ Ovigerous alveolus.

After the discharge of the generative products, the ovary is very small, occupying about a fourth of the reproductive organ, whereas the testis forms the main mass of the organ. With the activity of the tissues the 
ovary extends in length and may reach a size of about half of the gonad, but generally it occupies about a third of the mass and the testis twothirds. The ovigerous tissues dovetail into the spermatiferous tissues so that the surfaces of contact are irregular in outline but quite sharp on account of their respective colours.

\section{The Condition of the Eggs.}

On teasing a mature ovary, the ripe ova (Fig. 1, p. 610) are liberated, which possess a spherical cell-wall with brown deutoplasm uniformly distributed round the periphery. These eggs are usually over $80 \mu$ in diameter, and the nucleus is hardly visible through the cell-wall. In some of these ripe eggs the nucleus can be seen, and it occupies about a third of the cell. When these cells are liberated they do not adhere to one another, but separate quickly into individual ova. The largest number of individuals with this class of eggs was found among the samples examined between the first quarter and the full moon during the breeding season and to a smaller degree in September and October.

When the ripe ova are discharged, a few eggs, however, remain within the ovary, and these very soon start cytolizing, with the result that there is no clear cell membrane to the eggs $(50-70 \mu)$. On teasing such an ovary the smear shows a mass of naked nuclei in a brownish yolky matrix. This nutritive material is probably resorbed in the developing oocytes (Fig. 2, p. 612) in the follicles. The smallest oocyte observed was $30 \mu$.

The young oocytes $(30-50 \mu)$ are clear with a thin layer of light greencoloured yolk round the periphery, surrounded by an irregular cell-wall drawn out into spine-like processes. In these the nucleus, which is clear and vesicular, occupies nearly the whole of the cell and the nucleolus too is distinct. These young oocytes do not change their shape when artificially liberated. The greatest number of cases with this type of eggs was met with during the non-breeding season (July to January).

As development proceeds, the young oocytes pass through to an irregular polyhedral stage, in which the cells are between $50-80 \mu$ with a large quantity of nutritive material of a brown or brownish green colour, but not so much as to obscure the clear nucleus which is about half the size of the cell. If, at this stage, they be liberated artificially, a large number of the cells will adhere to one another for some time, though a few nearly ripe ones will separate. This stage in the development of eggs is, by far, the most frequent one found in the samples examined during the breeding season. As the oocytes become mature, the cell increases in size and the nucleus becomes obscured by the accumulation of yolk. 
The Presence or Absence of Ripe Sperms.

When a full creamy testis is punctured, a viscous fluid is extruded which shows a mass of non-active sperms in a gelatinous matrix. On adding sea-water, the non-active sperms become active and swim in the field. After such ripe products are discharged, the testis becomes collapsed and transparent; in this state, if the testis be teased, it reveals a few

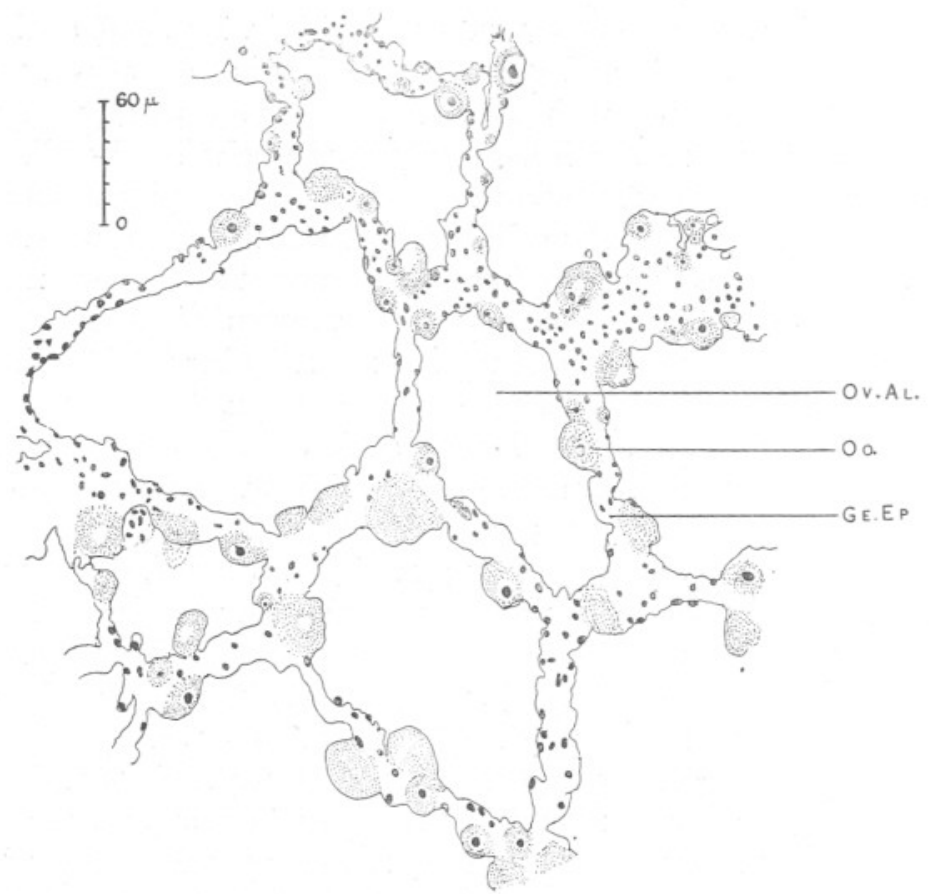

FIG. 2. A section through a spent ovary of Pecten opercularis.

GE. EP. = Germinal Epithelium.

Oo. $=$ Young oocytes.

Ov. AL. $=$ Ovigerous alveolus.

active sperms swimming in the liquid medium. This activity of the unspent sperms is due to the sea-water entering the spent testis. This is supported by the occurrence of a few turgid, transparent testes, which, on puncturing, collapse completely with the emission of a clear liquid.

As the tissues become active, the surface of the testis becomes honeycombed in appearance; this character is soon obliterated by the rapid development of the spermatocytes to form a white mass. At this stage there are no ripe sperms but spermatocytes only. With further develop- 
ment the white mass attains an opalescent and often a creamy appearance, and the mature sperms are produced, which possess a small ovate head somewhat drawn out at the apex. (Fullarton, 14, Fig. 2, Pl. 5.)

\section{Criteria of Ripeness and Unripeness in Males and Females DEFINED.}

The above-mentioned observations were made in order to fix a standard or standards by which an individual may be considered as ripe or as unripe. In the case of males, it is found that the collapsed and transparent or opaque testis contains few sperms and a large quantity of spermatocytes. This clearly indicates that such a testis is unripe. A full opalescent or creamy testis is considered as ripe as it contains sperms in abundance.

In the case of females, the distinction between the ripe and unripe is not clearly defined. The unripe individuals possess a "spent " or " half-full " ovary, light brown or red in colour with eggs not bigger than $80 \mu$. The ripe ovary may be distinguished by the fact that the eggs are bigger than $80 \mu$ and, further, the eggs do not adhere to one another when artificially liberated.

For the present paper an individual was recorded as ripe (1) in the case of females when $(a)$ the ovary was "full " and the eggs were over $80 \mu$, a size at which the eggs would segment on artificial fertilisation, e.g. No. 1, p. 633 ; (b) when the ovary was " half-full " and the eggs were over $90 \mu$, e.g. No. 3, p. 633 ; (2) in the case of males when $(a)$ the testis was " full " and creamy, e.g. No. 15 , p. 633 ; (b) the testis and the ovary were " full," e.g. No. 4, p. 633 .

These were the criteria used. To test the validity of these properties as tests of ripeness, artificial fertilisations were made from samples of May 18th and 26th and June 17th. From each sample six different individuals were used as females with eggs varying from $80 \mu$ to $100 \mu$ and six others as males with opalescent or creamy testis. In all cases there were about $90-95 \%$ of segmenting eggs.

The products of the generative organs in the same individual do not always ripen at quite the same time, though the interval that separates the ripening of the eggs and the sperms is usually not more than a few days. When the ova are ready to be shed, the spermatozoa have either been shed or are not quite ripe. Some gonads-about 10\% during the full-moon time - have been found with ova quite ripe and spermatozoa not ripe, while the others had ripe sperms and immature eggs. During the examination of all the samples, no individual was caught in the act of spawning. 


\section{The Periodicity in the Occurrence of Ripe Generative Products.}

The numerical results of the examination of the gonad are given in Table II, below, and Fig. 3, p. 616, and the detailed records of six samples from 9th March to 7th April on page 633. The dates on which the samples were obtained, and also the locality and the total number of specimens in each lot, are noted in the table. As already pointed out in Table I, p. 607 , the average size of the queens was about $50 \times 50 \mathrm{~mm}$. in all samples except those of 1st, 6th, and 29th July, 5th, 11th, 16th, and 30th August, and 19th September, in which the average was about $35 \times 35 \mathrm{~mm}$. On

\section{TABLE II.}

The Results of the Examination of the Samples for Ripe Individuals from the Fishing Grounds within a Radius of 25-30 miles of Plymouth.

\begin{tabular}{|c|c|c|c|c|c|c|c|}
\hline & & & No. & Ripe & nales & $\operatorname{Rip}$ & ales \\
\hline & $\begin{array}{l}\text { Date. } \\
1927 .\end{array}$ & Locality. & Total & No. & $\%$ & No. & $\%$ \\
\hline 18th I & February & Eddystone gds. & 257 & 51 & $19 \cdot 8$ & - & - \\
\hline $28 \mathrm{th}$ & , & & 151 & 37 & $24 \cdot 5$ & - & - \\
\hline $9 \operatorname{th} 1$ & Mareh & Trawling gds. & 180 & 84 & $46 \cdot 6$ & 95 & $52 \cdot 8$ \\
\hline 13 th & , & , & 178 & 83 & $46 \cdot 6$ & 102 & $57 \cdot 2$ \\
\hline 18th &, & , & 149 & 13 & $8 \cdot 7$ & 31 & $20 \cdot 8$ \\
\hline $23 \mathrm{rd}$ & , & , & 74 & 4 & $5 \cdot 3$ & 11 & $14 \cdot 8$ \\
\hline $29 \mathrm{th}$ & & , & 100 & 25 & $25 \cdot 0$ & 17 & $17 \cdot 0$ \\
\hline 7 th & April & , & 76 & 27 & $35 \cdot 5$ & 25 & $32 \cdot 8$ \\
\hline 15 th & ,, & ," & 104 & 31 & $29 \cdot 7$ & 42 & $40 \cdot 4$ \\
\hline $22 \mathrm{nd}$ & , &, & 109 & 28 & $25 \cdot 6$ & 32 & $29 \cdot 4$ \\
\hline 6 th 1 & May & Eddystone gds. & 100 & 28 & $28 \cdot 0$ & 21 & $21 \cdot 0$ \\
\hline 13 th & ,, & , & 100 & 40 & $40 \cdot 0$ & 37 & $37 \cdot 0$ \\
\hline $18 \mathrm{th}$ & , & , & 100 & 18 & $18 \cdot 0$ & 16 & $16 \cdot 0$ \\
\hline 26 th & , & , & 125 & 38 & $26 \cdot 1$ & 30 & $24 \cdot 0$ \\
\hline lst J & June & Trawling gds. & 100 & 27 & $27 \cdot 0$ & 26 & $26 \cdot 0$ \\
\hline 8th & , & Eddystone gds. & 100 & 37 & $37 \cdot 0$ & 23 & $23 \cdot 0$ \\
\hline 15 th & ," & Trawling gds. & 100 & 58 & $58 \cdot 0$ & 44 & $44 \cdot 0$ \\
\hline 17th & ,, & ,, & 100 & 50 & $50 \cdot 0$ & 41 & $41 \cdot 0$ \\
\hline 21 st & & , & 125 & 1 & $0 \cdot 8$ & 1 & $0 \cdot 8$ \\
\hline 1st J & July & Mewstone gds. & 100 & 6 & $6 \cdot 0$ & 5 & $5 \cdot 0$ \\
\hline 6 th &, &, & 95 & 7 & $7 \cdot 3$ & 4 & $4 \cdot 2$ \\
\hline 13 th & , & Eddystone gds. & 100 & 2 & $2 \cdot 0$ & 2 & $2 \cdot 0$ \\
\hline 21 st &, & Trawling gds. & 144 & 4 & $2 \cdot 7$ & 4 & $2 \cdot 7$ \\
\hline 26 th & ,, & , & 119 & 18 & $15 \cdot 1$ & 19 & $15 \cdot 9$ \\
\hline 29 th &, & Mewstone gds. & 86 & 0 & 0 & 0 & 0 \\
\hline 5 th & August & ," & 135 & 2 & $1 \cdot 4$ & 0 & 0 \\
\hline 11 th & , & , & 100 & 0 & 0 & 0 & 0 \\
\hline 16 th & , & , & 62 & 1 & $1 \cdot 6$ & 1 & $1 \cdot 6$ \\
\hline 17 th & , & Eddystone gds. & 160 & 0 & 0 & 0 & 0 \\
\hline 23rd & ," & ," & 35 & 0 & 0 & 0 & 0 \\
\hline 30 th & , & Mewstone gds. & 164 & 0 & 0 & 1 & $0 \cdot 6$ \\
\hline 9 th $\mathrm{s}$ & September & Trawling gds. & 165 & 5 & $3 \cdot 0$ & 5 & $3 \cdot 0$ \\
\hline 14th & ," & Eddystone gds. & 180 & 0 & 0 & 1 & 0.5 \\
\hline 19 th & $"$, & Mewstone gds. & 37 & 0 & 0 & 0 & 0 \\
\hline 20 th &, & Trawling gds. & 200 & 0 & 0 & 0 & 0 \\
\hline 27 th & ,, & ", & 170 & 0 & 0 & 0 & 0 \\
\hline
\end{tabular}


TABLE II-continued.

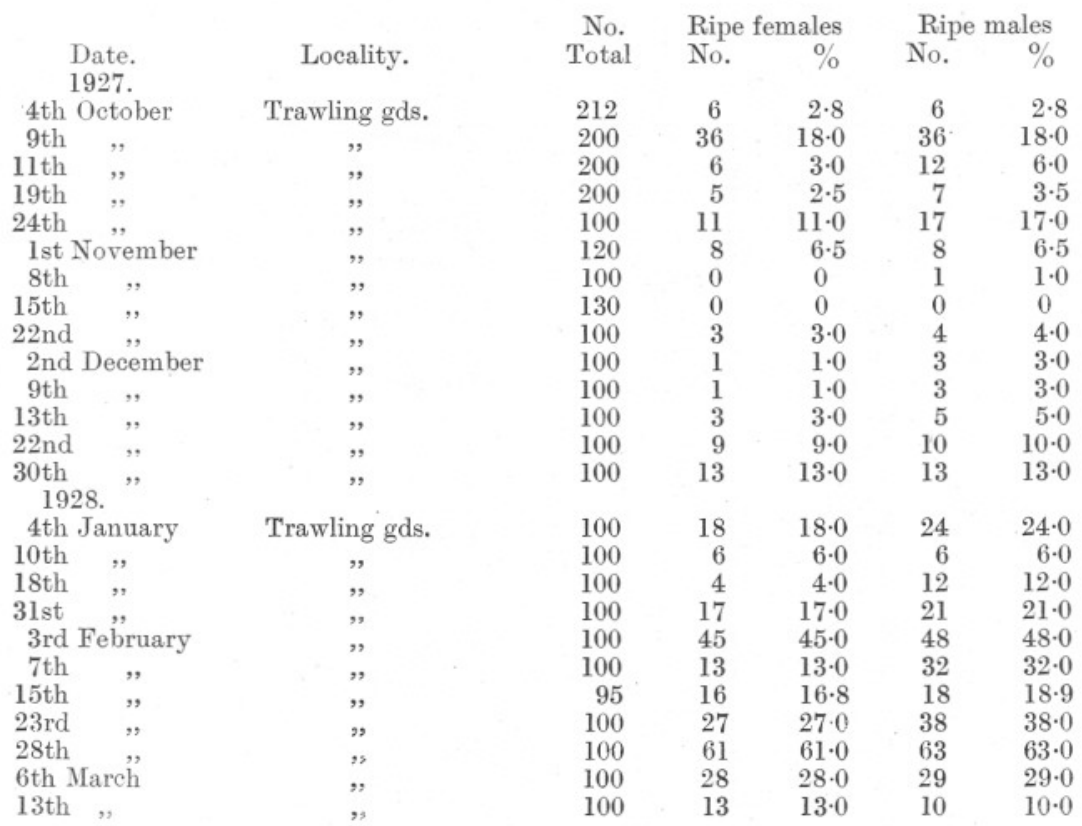

each occasion a fair number of individuals was examined ; on 9th April, 23rd August, and 19th September, only a small number could be obtained. Owing to bad weather an absence in sampling during the period from 8th to 16th April occurs, when no specimens were examined between the two dates. The results represent the ripe individuals in percentages of totals examined.

The curve (Fig. 3) can be conveniently divided into two sections: (a) February to June, 1927, and January to March, 1928; (b) June to December, 1927. The first section is for the breeding season and the second for the non-breeding season.

In the first half of the figure, the curves show :-

(1) a close correspondence between the male curve and the female curve, i.e. they rise and fall together.

(2) The four apices of the curve for March, April, May, and June, 1927, and the three for January, February, and March, 1928, occur during the full-moon time.

(3) The minima do not touch the zero ordinate till the breeding season approaches the end.

(4) The ripening of the sexual products seems to be correlated with the oncoming of the full moon. 


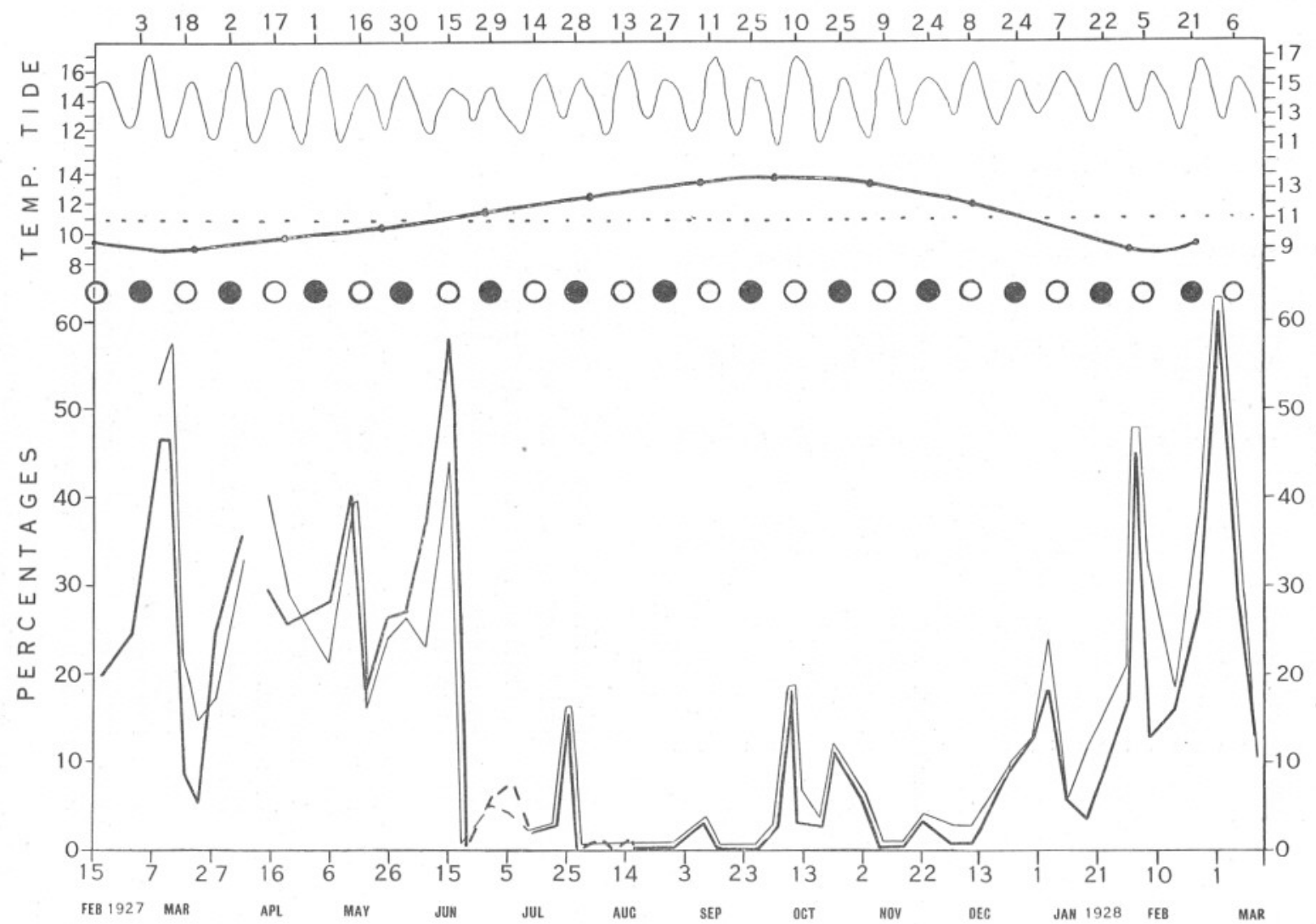

FIG. 3. Graph showing the percentages of nearly ripe or ripe specimens of Pecten opercularis in relation to the moon's phase, indicating a regular correlation between lunar periodicity and the breeding phenomenon. The samples of queens were obtained from the trawling grounds within a radius of $25-30$ miles of Plymouth.

The thick continuous line denotes the frequency of ripe females; the thin continuous line, that of the ripe males. The thick and the thin discontinuous lines represent the samples from Mewstone. Full moons are shown by circles and the new moons by the filled-in cireles here and in Fig. 4.

At the top of the figure the tide - in feet-is shown by the thin line, and the curve for monthly temperature-in degrees Centigrade - at the bottom, at Station El $\left(50^{\circ} 02^{\prime} \mathrm{N} . ; 4^{\circ} 22^{\prime}\right.$ W.; depth 70 metres $)$, is denoted by the thick line. [The temperatures at Station El were recorded by Mir. H. W. Harvey, to whom the writer is indebted for the data.] 
(5) The temperature ranges between $8.9^{\circ} \mathrm{C}$. and $11^{\circ} \mathrm{C}$.

(6) No correlation between the new moon spring tides and the spawning time is shown.

Between the third quarter and the new moon in February, March, April, May, and June, 1927, and January, February, 1928, about $70 \%$ of the queens were found to contain large oocytes and spermatocytes; about $10 \%$ were in a collapsed condition with few, unspawned, degenerating eggs in the ovary; and the rest were found with gonads full of eggs and sperms.

Between the new moon and the first quarter, during the breeding season, there were about $5 \%$ of " spent" individuals; about $50 \%$ with developing eggs and sperms approaching maturity ; and the rest contained eggs and sperms ready to be shed.

Between the first quarter and the full moon of the spawning season, the maximum number of ripe individuals occur. In addition to this there is about $35 \%$ of individuals with developing oocytes and spermatocytes. These will not reach maturity at the lunar period in question, but are those that have already spawned earlier in the year. At this stage, too, there are about $5 \%$ of " spent" ones present.

Between the full moon and the third quarter, the minimum number of mature individuals occurs. The percentage of "spent" gonads has increased, but the main bulk of the individuals contain developing oocytes and spermatocytes.

The second half of the curve from June to December shows : (1) A correspondence between the male curve and the female curve. (2) The breeding season approaches its end after June spawning. (3) The apices of the curve for July and the latter part of October occur during the new moon time ; there is no spawning in August, November, and December; and the apices for September and the early part of October correspond with the full moon time. (4) The temperature has risen above $11^{\circ} \mathrm{C}$.

It is interesting to note that at all times during the breeding season there is a large percentage of individuals with developing ovary. Further, the samples examined in July and in the early part of August were developing normally as if spawning was to occur at the August full moon; however, after the August full moon - sample taken on 17th August - the ovary of the specimens was still in a turgid condition. thus suggesting that no spawning had taken place.

In Table III (p. 618) and Fig. 4 the numerical results and the graphical representation of individuals with developing ovary for May, June, July, and August, are expressed in percentages of totals. The curve for each of the four months falls with the full moon, and hence the repetition of the same phenomenon for each of the months would be expected; but in nature, the developing eggs in May and in June reach maturity and are 


\section{TABLE III.}

The Results of the Examination of Samples for Individuals with Developing Ovary in May, June, July, and August, 1927.

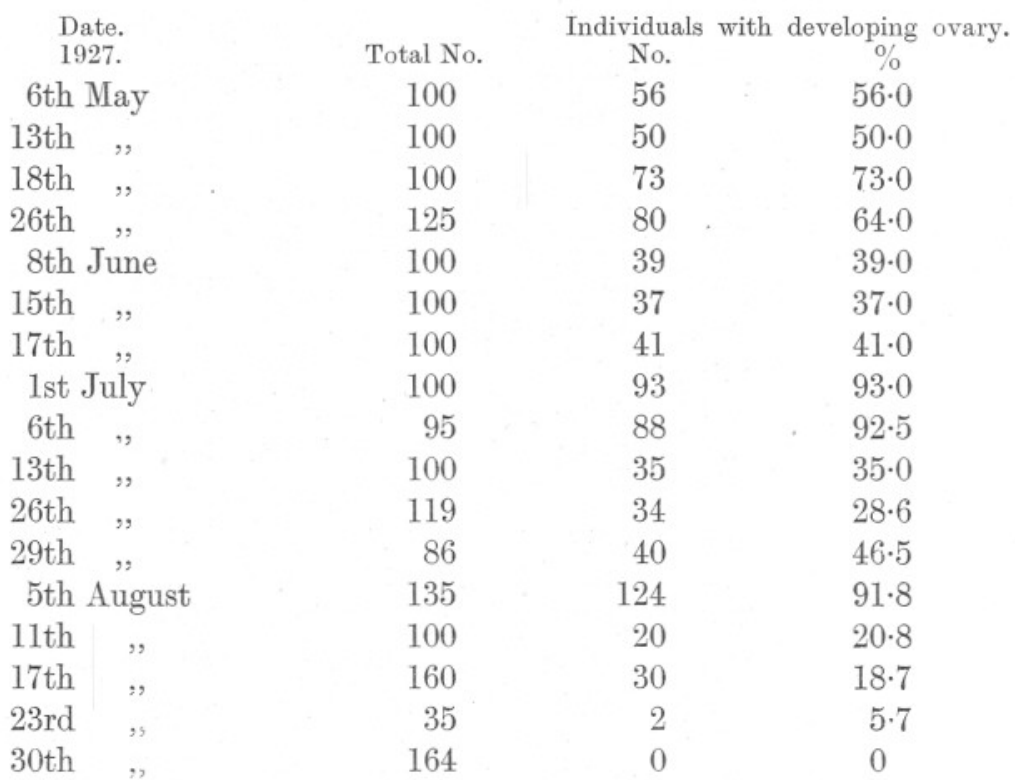

spawned, whereas those of July and of August are not spawned-as shown previously in Fig. 3, p. 616-but degenerate after the full moon. Hence this behaviour of the eggs in July and in August signifies the possibility of a physiological rhythm in the animal.

\section{The Gut Contents of the Queens.}

For the development of the genital products, a large amount of material is necessary. The source from which such material can be obtained is either from the tissues of the animal - as in the case of salmon's ovaries which develop at the expense of muscles (21) - or from the food that is taken into the gut by feeding.

Since no chemical analysis of tissues from weekly samples of $P$. opercularis has been made, it is not possible to state definitely whether the tissues are a source of nutrition or not to the developing gonad. However, it may be mentioned that "spent" individuals gape in a shorter time than those with developing or ripe gonad when left out of water. This seems to suggest that a certain amount of nutritive material is obtained 
by the developing gonad at the expense of adductor muscles, or that during spawning the animal swims vigorously.

To test whether the quantity of food present in the gut varied during a lunar month, weekly examinations of fifty individuals - of approximately the same size-were made for two months. The gut contents were extracted by an apparatus similar to the one used by Moore for

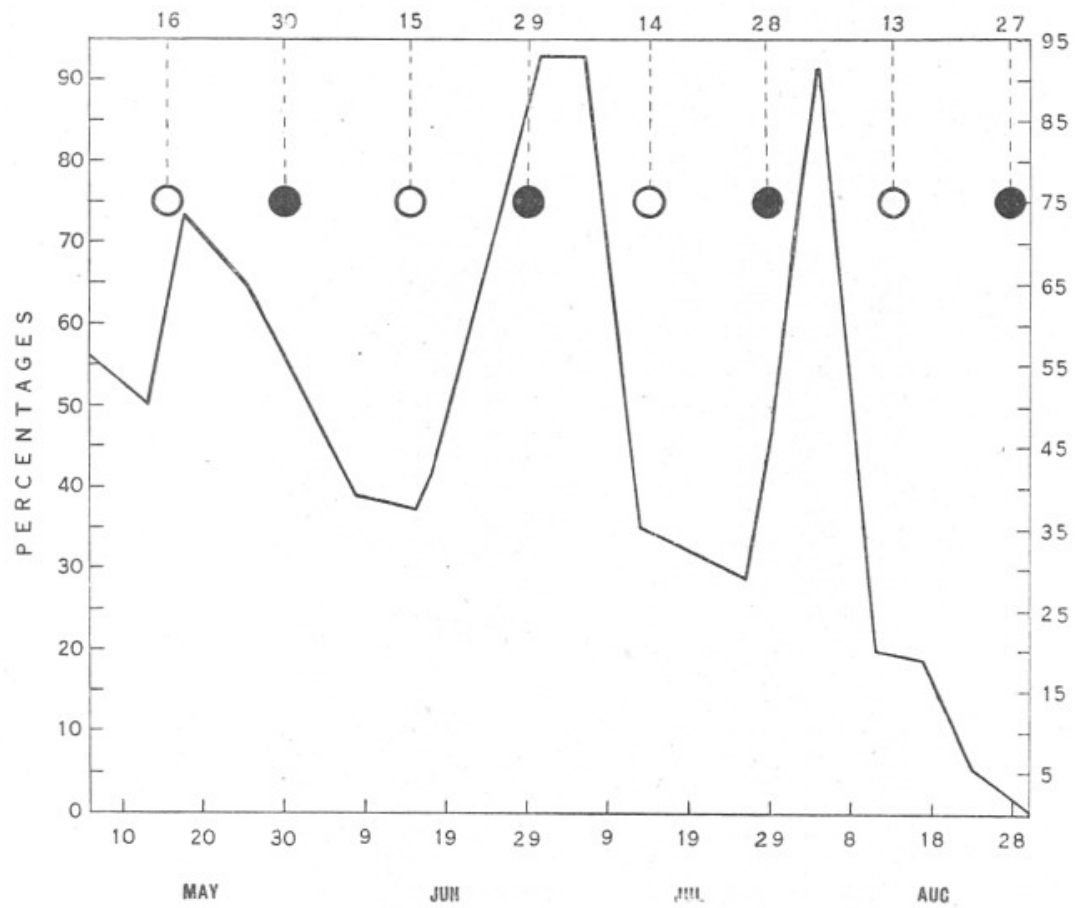

FIG. 4. Graph showing the percentages of individuals of Pecten opercularis with developing ovary for May, June, July, and August, 1927.

oysters (42, Fig. 6, p. 1305), preserved in 10\% formalin and allowed to settle down. On roughly comparing the residue of all the samples, it was observed that there was no appreciable difference in quantity of the food. On microscopic examination of the residue it was noted that the same type of diatoms and flagellates occurred with a fair quantity of detritus, thus, suggesting that the nature of the food was the same.

The Experiment on Quenns with Moonlight.

Macht (38) and Garner and Allard (17) have shown that polarised light or the length of daylight has an influence on the growth of plants. Rowan (52, p. 183) has suggested that bird migration is due to an " environmental 
controlling factor provided by the varying day lengths" among other factors. Mayer on Atlantic palolo (41, p. 110) states, "I had floating scows similar to those used in the previously described experiment, but they were provided with light-tight wooden covers, so that they could be closed at sunset every evening and exposed soon after sunrise every morning, thus preventing the moonlight from falling upon the rocks. Although I had at least 22 mature worms . . . but none of these worms showed any indication of swarming, and it appears that they could not respond owing to the absence of light." Treadwell $(60)$ on the same annelid is of opinion that the presence of moonlight is not necessary for swarming reaction. Further, Grave, on the spawning habit of Chatopleura apiculata (18, p. 240),

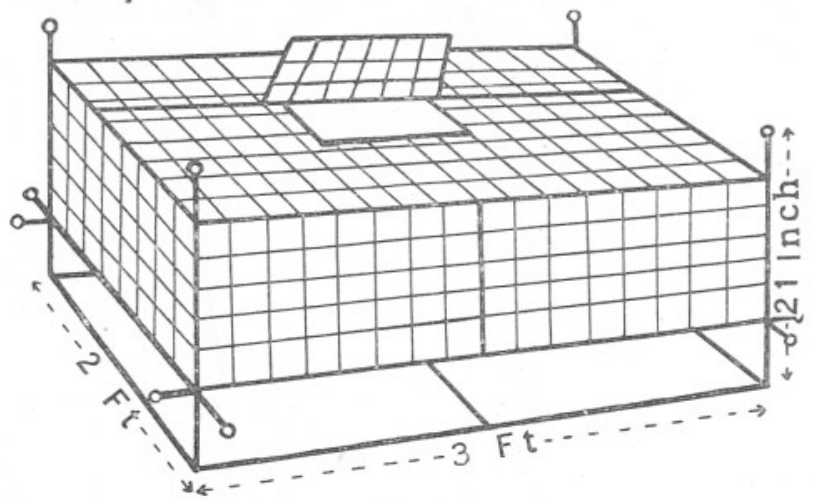

FIG. 5. A diagram showing the type of eage used for the experiment on queens with moonlight. The iron wire which forms the framework is represented by the thick line, and the galvanized wire by the thin line.

There are two bottoms to this cage, one true and the other false. The purpose of the false bottom is to prevent the cage from sinking into the sand and thus causing bad circulation in the cages that are covered by canvas.

states, " both sexes are apparently affected by the change of running to quiet water (tide changes), presumably also by the change in pressure between high and low tides (mechanical shock) and most certainly by moonlight" (italies not in the original). Since there are conflicting views in the literature on the effect of moonlight on spawning habits, the following experiment was carried out at Pier Cellars* in Cawsand Bay to find the influence of moonlight - if any - on the rhythmic reproduction of queens.

Specimens of Pecten opercularis were trawled from the Eddystone grounds on the 13th July, kept under circulation on board the s.s. Salpa

* Pier Cellars was selected for this experiment as the water is clean and the bottom sandy. Further, there is no dilution or change of $\mathrm{pH}$ due to rivers. At the lowest spring tides the cages were covered by about two fathoms of water and at the highest by 4 to $4 \frac{1}{2}$ fathoms. 
and transferred into three cages - similar to those used by Dr. Orton in experiments on oysters (45) - at Pier Cellars. About 300 individuals were kept in each of the cages at the beginning of the experiment and 50 were taken out from each cage every week for examination.

The details of the cage are given in Fig. 5 (p. 620).

Cage A was left open to both sunlight and moonlight.

Cage B was left open to sunlight but not to moonlight.

This result was obtained by covering the cage with a tarred canvas hood every evening, and by removing it every morning just after sunrise.

Cage $\mathrm{C}$ was kept covered day and night by a canvas cover except when samples were required.

TABLE IV.

The Results of the Examination of Weekly Samples from Experimental Cages showing the Condition of the Eggs.

\begin{tabular}{|c|c|c|c|c|c|c|c|c|c|}
\hline \multirow{3}{*}{$\begin{array}{l}\text { Date } \\
1927\end{array}$} & \multirow{2}{*}{\multicolumn{3}{|c|}{$\begin{array}{l}\text { Young oocytes. } \\
30-50 \mu \text { diameter }\end{array}$}} & \multicolumn{3}{|c|}{$\begin{array}{l}\text { Developing eggs. } \\
50-80 \mu \text { diameter }\end{array}$} & \multicolumn{3}{|c|}{$\begin{array}{l}\text { Degenerating eggs. } \\
50-70 \mu \text { cytolizing }\end{array}$} \\
\hline & & & & A & B & $\mathrm{C}$ & A & B & $\mathrm{C}$ \\
\hline & $\%$ & $\%$ & $\%$ & $\%$ & $\%$ & $\%$ & $\%$ & $\%$ & $\%$ \\
\hline 13th July & 71 & 71 & 71 & 37 & 37 & 37 & 2 & 2 & 2 \\
\hline 14th , & & & & & & & & & \\
\hline 20 th & 68 & 98 & 96 & 20 & 2 & 2 & 12 & none & 2 \\
\hline $21 \mathrm{st}$ & & & & & & & & & \\
\hline $\begin{array}{l}27 \text { th } \quad " \\
28 \text { th }\end{array}$ & 40 & 76 & 64 & 30 & 24 & 36 & none & none & none \\
\hline $\begin{array}{l}\text { 3rd August } \\
5 \text { th },\end{array}$ & 20 & 60 & 24 & 80 & 40 & 76 & none & none & none \\
\hline 10th , & 4 & 6 & - & 86 & 86 & - & 10 & 8 & - \\
\hline 15 th & & & & & & & & & \\
\hline 16th , & 2 & - & none & 62 & - & 78 & 36 & - & 22 \\
\hline
\end{tabular}

As there was heavy mortality in cages $\mathrm{B}$ and $\mathrm{C}$ due to predaceous crabs and gastropods, the stock was considerably reduced, and hence only five weekly samples were taken from each of these cages.

From Table IV it is evident that :-

(1) The development of the ovary under these conditions is independent of sunlight and moonlight.

(2) The individuals with degenerating eggs occur during the full moon time. It will be also noticed that the number of individuals with young oocytes throughout the period of experiment is predominant in Cage B. This result is probably due to the disturbance caused by the Cage B being 
hauled up above the water every morning and evening to attend to the cover.

Although the experiment was carried out at the end of the breeding season-without the knowledge that June spawning was the last for $P$. opercularis in 1927 -yet the experiment recalled the suggestion that in the animal there was a physiological rhythm which synchronised with the full phase of the moon.

\section{Plants and Moonlight.}

The belief in the beneficial effect of moonlight on plant-growth is world-wide and ancient. Musset (43) showed that flowering plants are positively phototropic to moonlight. Loftfield $(\mathbf{3}$ ) states that the stomata open in moonlight. Wright (64) found that at new moon and at full moon practically none of the reflected light is polarised; the greatest amount of polarisation is obtained about the end of the first and third quarters of the moon. Baly and Semmens (3) showed that plane-polarised light exercises a powerful acceleration on the hydrolysis of starch by diastase. Knaute's (32) figures show that the photosynthetic effect of moonlight with a ratio to that of sunlight is $2: 9$ although the intensity of the light of the sun is about 618,000 times greater than that of the full moon. Yoshii (65) found that the rate of growth is proportional to the length of daily exposure to light. Garner and Allard (17) state, "it is apparent that with the plants in which flowering is favoured by short days as well as with those in which the opposite is true, the general effect of the relatively short alternations of light and darkness on reproductive activity is much the same as that produced by long days or by continuous illumination." Kofoid (33) found that there was an algal maximum in the plankton in Illinois River during full moon time. Allen (1), too, found a similar increase in the number of green organisms in San Joaquin River as the light of moon increased. Among plants there are authentic cases of lunar rhythm in reproduction known. They are :-

(1) Neoderma ; Heligoland; bilunar (neap tides). Kuckuck (34), 1901.

(2) Dictyota dichotoma; Plymouth, Bangor; bilunar. Williams (63), 1905.

(3) Dictyota dichotoma; Beaufort, N. Carolina; lunar. Hoyt (25), 1907.

(4) Sargassum; Japan ; bilunar (neap tides). Tahara (57), 1909.

(5) Dictyota dichotoma; Naples; Bilunar (neap tides). Lewis (35), 1910.

It is interesting to note that Dictyota dichotoma at Bangor and Naples has two reproductive cycles per lunation, whereas the same species at 
North Carolina has only one cycle per lunation. Yet the average tidal range at Bangor is $5 \cdot 4$ metres, at Naples is 0.3 metres, and at Beaufort, North Carolina, is 0.8 metres.

\section{Lunar Periodicity already Described in Animals.}

\section{Ceglenterata.}

Obelia geniculata; Millport ; full moon. Elmhirst (10), 1925.

\section{Echinodermata.}

Toxopneusthes variagatus; Tortugas ; full moon. Tennett (58), 1910.

Centrechinus (Diadema) setosus; Suez; full moon. Fox (12), 1923.

\section{Polycheta.}

Leodice viridis *; Samoa; third quarter. Whitmee (62), 1875.

Leodice fucata ; Tortugas ; third quarter. Mayer (39), 1900.

Ceratocephale osawai; Japan; new and full moon. Izuka (2\%), 1903.

Convoluta roscoffensis; Brittany; new and full moon. Gamble and Keeble (16), 1903.

Lysidice oele; Malay Archipelago; second and third nights after full moon. Horst (24), 1905.

Amphritrite ornata; Woods Hole; within two days of new or full moon. Scott (54), 1909.

Nereis dumerilii; Naples; first and third quarter. Hempelman (23), 1911.

Odontosyllis enopla; Flatt's Island; third quarter. Galloway and Welch (15), 1911.

Nereis limbata; Woods Hole; between full moon and third quarter and third quarter and new moon. Lillie and Just (36), 1913.

Platynereis megalops; Woods Hole; between full moon and new moon. Just (29), 1914.

Eulatia punctifera; Concarneau ; third quarter. Fage and Legendre (11), 1926.

\section{Mollusca.}

Chiton tuberculatus; Bermuda; full moon. Crozier ('), 1920.

Chatopleura apiculata; Woods Hole; between full moon and third quarter. Grave (18), 1922.

Ostrea edulis ; Falmouth ; full moon, 1925. Orton (46), 1926.

Cumingia tellinoides; Woods Hole; full moon. Grave (19), 1927.

* The Palolo worms have received several names. Tredwell's (61) identifications are followed in this paper. 
Pisces.

Leuresthes tenuis; California; second, third, and fourth nights after full moon and after new moon. Thompsons (59), 1919, Clark (5), 1925 .

Mammalia.

Homo sapiens. Arrhenius (2), 1898.

In the case of those animals with two reproductive cycles in each lunar month, the chief factor causing the rhythm is probably tidal as shown by Clark (5) in the case of Leuresthes tenuis. In those with only one cycle per lunation, various explanations have been put forward. Mayer (41), as already pointed out on p. 620 of this paper, stated that moonlight is the effective cause and that the tides are unnecessary but contributing factors for the swarming of the Polychæte Leodice fucata. In contradiction to this, Treadwell (60) showed that moonlight is not necessary for the swarming of this annelid. Lillie and Just (36) and Fox (13) have shown that males stimulate the females to spawn, and that, in the case of Nereis limbata, the males are stimulated by some chemical stimulus extruded from the eggs of ripe females. But this does not explain the lunar periodicity in reproduction.

Arrhenius (2) has shown statistically that there exists a low correlation between the frequency of human births and the sidereal lunar month of $27 \cdot 32$ days. The same periodicity was found for menstruation, but to a more pronounced degree.

\section{Discussion on the Probable Causes of Periodicity IN Reproduction.}

It has now been shown that there is a rhythmic periodicity in reproduction in Pecten opercularis, and that maximum spawning occurs about the full moon time. In order to explain satisfactorily why the queens spawn rhythmically, it would be necessary to detect the factors-internal or external-that would act periodically. Further, it would also be important to find out the factor that causes the queens to spawn at full moon time.

The rhythmic effect of the alternating spring and neap tides has already been described in some animals. In Convoluta roscoffensis, Keeble (30) has shown that the rhythm of egg-laying is so well established in this planarian that it keeps its habit of laying its eggs at neap tides even if reared in the Laboratory. Leuresthes tenuis, an atherine fish, spawns periodically on each series of high tides throughout the breeding season in California (Clark, 5). Pecten opercularis has only one reproductive cycle each lunar month though there are two spring tides and two neap tides. 
Nevertheless, it may be pointed out that spawning seems to occur at the beginning of the full moon spring tides after the neap of the first quarter. Further, the average excess tidal range of the new moon spring over that of the full moon spring, during the breeding season, was not more than two feet. This difference could scarcely effect the queens, especially as they are active migrants. In order to test whether the rhythmic habit of this mollusc was a well-established physiological rhythm or not-as in Convoluta-samples were kept in the Laboratory tanks. These individuals showed no signs of reproductive activity, but had the healthy eggswhich were present when they were captured in nature-degenerating, probably due to their captivity. This experiment, therefore, is not sufficient to state whether or not the spawning habit is a well-established cycle.

The presence of a large percentage of individuals with well developing gonad at all times during the breeding season, suggests that (1) the time taken for the production of a new crop of ripe sexual products is more than a lunar month, and (2) the early development of the oocytes and spermatocytes takes place in a relatively short time. Microscopic sections of mature ovaries (Fig. 1, p. 610) show that young oocytes are present in the walls of the follicles and ripe ova in the ducts. Sections of "spent" ovaries (Fig. 2, p. 612), too, possess similar young oocytes in the follicular wall. Hence it is suggested that both the above-mentioned factors contribute to the presence of a large proportion of individuals with developing eggs.

For the development of generative products, a large amount of nutritive material is necessary. The sources from which such material can be obtained are either from the tissues of the body or from the intake of the food or from both. It has already been indicated (p. 618) that the quantity of food in the gut is apparently constant, and hence does not contribute directly to the rhythmic ripening of the gonad.

The lunar periodicity of reproduction among plants is easily explained by the effect of polarised light on photosynthesis. But in the case of animals, the reason is not so clear, except in those which have two reproductive cycles per lunar month. Grave (18) states that moonlight has direct influence on both sexes of Chatopleura apiculata. The experiment described on p. 619 suggests, at least, that moonlight has no effect on the development of the sexual products of Pecten opercularis, although unfortunately the experiment was carried out at the end of the breeding season. Further, this species of Pecten normally occurs at a depth of 20 fathoms or more, where the amount of light from the moon is negligible, as the work of Poole and Atkins (51) on sunlight shows. They state that " the clearest water, 20 miles out in the English Channel, gave an absorption coefficient $0 \cdot 110$ for the upper 10 metres, $0 \cdot 117$ for the second and 
0.133 for the third. This water with glassy surface transmitted $0.54 \%$ of the vertical illumination to $34 \cdot 8$ metres " (about 19 fathoms. Italics mine), " $28.3 \%$ to 8.3 metres, at which depth a white dise was just visible, and $71 \cdot 2 \%$ to 1.5 metres." Lillie and Just (36) make the assumption that the maturity of the animals is dependent on some relation of the life-history to the phases of the moon, involving, probably through lunar tidal variations, rhythmical alternation of the condition of nutrition.

\section{Conclusions regarding the Phenomenon Recorded.}

It has been pointed out that the lunar periodicity in reproduction is not caused by (1) tidal effects, (2) food, and (3) direct light of the moon, individually, although the cumulative effect of these factors may be responsible; but there is no proof to decide one way or the other.

The correlation between the cessation of spawning in Pecten opercularis and the rise of temperature or the beginning of the spawning with the fall of temperature (Fig. 3, p. 616) indicates that the temperature has a controlling effect on the spawning habits of this mollusc, i.e. as long as the temperature remains favourable to the animal the spawning will occur mainly at full moon time. Orton (44) has shown that the European oyster (Ostrea edulis) " begins to spawn in a mean temperature of $15^{\circ}$ $16^{\circ} \mathrm{C}$. throughout its geographical range. Further, this species continues to produce mature sexual products so long as the temperature remains above the figure." Fox (12), discussing the effect of temperature on Centrechinus setosus, states, "its breeding season begins at Suez some months previous to July at a temperature well below that of July and September. Yet from July onward, with the temperature still rising, the number of individuals reaching maturity declines, and in September all breeding ceases although the temperature is still above that at which the breeding season was initiated." In the case of Pecten opercularis the temperature seems to have the same effect as it has on Centrechinus. As long as the temperature remains below $11^{\circ} \mathrm{C}$., spawning seems to occur normally; but when the temperature rises above $11^{\circ} \mathrm{C}$. breeding ceases. Hence it would appear that there is a maximum temperature limit of about $11^{\circ}$ C. for Pecten opercularis above which the breeding of the species stops. This, with the work of Orton and Fox, suggests that there is a maximum and a minimum temperature limit for each species of the marine animals, between which temperatures breeding mainly occurs.

It may be mentioned here that the geographical distribution of $P$. opercularis is mainly confined to Europe. Bucquoy, Dautzenberg, and Dollfus (4) state, "Le $P$. opercularis est très abondant dans la Mediterranée et l'Adriatique sous la forme Andouine; la forme typique est 
au contraire très répandue dans l'océan, depuis le détroit de Gibralter jusqu'en Norvège, ainsi qu'aux îles Madère, Canaries, et Açores."

It has already been pointed out in Table III, p. 618, and Fig. 4, p. 619, that the ovary of $P$. opercularis was developing normally in early July and in the early part of August as if spawning was to take place with August full moon, but there was no spawning, and still the eggs were degenerating after the full moon of the 13th August. This seems to suggest that in the animal there is a physiological rhythm that causes the development of the gonad to coincide with the full moon phase of each lunar month.

\section{ACKNOWLEDGMENTS.}

I should like to take this opportunity to express my gratitude to the Council of the Marine Biological Association for its kind hospitality extended to me to work in its Laboratory, and also for the facilities afforded me to carry out the present work. I am also indebted to Dr. Allen for his encouragement and help ; to Mr. E. Ford and other members of the Staff for their kindness ; to Mr. Brimmacombe for his information on the popular belief on lunar periodicity of queens; and especially to Dr. J. H. Orton for his criticisms and advice during the course of my work.

\section{SUMMARY.}

1. It has been shown that there is a lunar periodicity in reproduction of $P$. opercularis near Plymouth in 1927-28. The ripening of sexual products corresponds with the full phase of the moon.

2. The condition and shape of the gonad changes with the development of the tissues.

3. The colour, too, of the hermaphrodite organ changes with development.

4. Black pigmentation has been observed on the gonad in thin-shelled $P$. opercularis, a phenomenon apparently due to actinic rays penetrating the thin shell.

5. The breeding season is from January to June inclusive.

6. The gut contents seem to show no appreciable difference either in quantity or in the nature of the food during a lunar month.

7. The moonlight has apparently no effect on the lunar periodicity in reproduction.

8. It is suggested that in the animal there is a physiological rhythm that causes the development of the gonad to coincide with the full moon of each lunar month. 


\section{LITERATURE.}

1. Allen, W. E. A quantitative and statistical study of the Plankton of the San Joaquin River. Cal. Univ. Pub. Zool., Vol. 22, p. 1 (1921-23).

2. Arrhenius, Svante. Die Einwirkung kosmicher Einflüsse auf physiologische Verhältnisse. Skand. Arch. f. Physiol., Vol. 8, p. 367 (1898).

3. Baly, E. C. C., and Semmens, E. S. The selective Photochemical action of polarised light. Proc. Roy. Soc. B., Vol. 97, p. 250 (1924).

4. Bucquay, E., Dautzenberg, Ph., Dollfus, G. Les Mollusques Marines des Roussilon, Tome 2, p. 79. Paris (1898).

5. Clark, Frances N. The Life-history of Leuresthes tenuis, an atherine fish with tide-controlled spawning habits. Cal. Fish. \& Game Com. Fish. Bull., No. 10 (1925).

6. Clark, Frances N. The Conservation of the Grunion. Cal. Fish. \& Game, Vol. 12, p. 161 (1926).

7. Crozier, W. J. An observation on the Cluster-formation of the sperms of Chiton. Am. Nat., Vol. 56, p. 478 (1922).

8. Dakin, W. J. Pecten. L.M.B.C., Memoirs XVII (1909).

9. Dautzenberg, P. Contribution à la fauna malacologique de l'Afrique occidentale. Actes Soc. Linn., Bordeaux, Vol. 64, p. $47(1910)$.

10. Elmhirst, R. Lunar Periodicity in Obelia. Nature, Vol. 116, p. 358 (1925).

11. Fage, L., et Legendre, R. Essaimage et rythme lunare d'un Phyllodicen. (Eulatia punctifera. Grube.) Compt. Rend. Acad. Sci., Paris, Vol. 182, p. 721 (1926), and Biol. Absts., Vol. 1, p. 392 (1927).

11a. Fage, L., et Legendre, R. Pêches Planctoniques à la lumière effectuées à Banyuls-sur-mer et à Concarneau. Arch. Zoo. Exp., Tome 67, p. 23 (1927).

12*. Fox, H. Munro. Lunar Periodicity in Reproduction. Proc. Roy. Soc. B., Vol. 95, p. 523 (1923).

\footnotetext{
* This work contains a good list of literature.
} 
13. Fox, H. Munro. The Spawning of Echinoids. Proc. Camb. Phil. Soc. Biology, Vol. 1, p. 71 (1924).

14. Fullarton, J. H. Development of Scallop. 8th Report Fish. Bd. Scot., p. 290 (1890).

15. Galloway, T. W., and Welch, P. S. Studies on a Phosphorescent Bermudan Annelid, Odontosyllis enopla. Verrill. Trans. Am. Micro. Soc., Vol. 30, p. 13 (1911).

16. Gamble, F. W., and Keeble, F. The Bionomics of Convoluta roscoffensis. Quar. Journ. Micro. Soc., Vol. 47, p. 363 (1903-4).

17. Garner, N. W., and Allard, H. A. Effect of short alternating periods of light and darkness on Plant Growth. Science, Vol. 66, p. 40 (1927).

18. Grave, B. H. An Analysis of the spawning habits and spawning stimuli of Chatopleura apiculata. Biol. Bull., Vol. 42, p. 234 (1922).

19. Grave, B. H. An Analysis of the spawning habits and spawning stimuli of Cumingia tellinoides. Biol. Bull., Vol. 52, p. 418 (1927).

20. Grave, B. H. The Natural History of Cumingia tellinoides. Biol. Bull., Vol. 53, p. 208 (1927).

21. Greene, Chas. W. The Physiology of the spawning migration. Physiol. Rev., Vol. 6, p. 201 (1926).

22. Hass, F. Lamellibranchia. Die Tierwelt der Nord- und Ost-see, Tiel. IX d1, p. 41 (1926).

23. Hemplemann, F. Zur Naturgeschichte von Nereis dumeritii. Zoologica, Vol. X, 25, p. 1 (1911).

24. Horst, R. Over Wawo (Lysidice cele. n. sp.) Rumphius Gedenkboek Kolon. Mus., Haarlem, p. 105 (1905).

25. Hoyт, W. D. Periodicity in the reproduction of the sexual cells in Dictyota dicotoma. Bot. Gaz., Vol. 43, p. 383 (1907).

26. Hunt, O. D. The Food of the Bottom Fauna of the Plymouth Fishing Grounds. Journ. Mar. Biol. Assoc., Vol. 13, p. 560 (1923-25).

27. Izuka, A. Observations on the Japanese Palolo Ceratocephale osawaii. Journ. Coll. Sci., Tokio, Vol. 17, Art. 11 (1903).

28. Jones, W. N. Selective action of polarised light upon starch grains. Nature, Vol. 117, p. 15 (1926), and Biol. Absts., Vol. 1, p. 449 (1927). 
29. Just, E. E. Breeding habits of the heteronereis form of Platynereis megalops at Woods Hole, Mass. Biol. Bull., Vol. 27. p. 201 (1914).

30. Keeble, F. Plant-animals. Cambridge (1912).

31. Klincksieck et Vallete. Code des Couleurs. Paris (1908).

32. Knaute, K. Der Kreislauf der Gase in unseren Gewässern. Biol. Cent., Vol. 18, p. 785 (1898).

33. Koford, C. A. Planktonic Studies. Bull. Ill. State Lab. Nat. Hist., Vol. 8, p. 1 (1908-10).

34. Kuckuck, P. Neue Untersuchungen über Nemoderma. Wiss. Meeresunters. Abt. Helgoland. N.F., Vol. 5 (1901).

35. Lewis, I. F. Periodicity in Dictyota at Naples. Bot. Gaz., Vol. 50, p. 59 (1910).

36. Lillie, F. R., and Just, E. E. Breeding habits of the heteronereis form of Nereis Limbata at Woods Hole. Biol. Bull., Vol. 24, p. 147 (1913).

37. Loftfield, J. V. G. The behaviour of Stomata. Carnegie Inst., Wash., Pub. No. 314 (1921).

38. Macht, David I. Concerning the influence of polarised light on the growth of seedlings. Jour. Gen. Physiol., Vol. 10, p. 41 (1926), and Biol. Absts., Vol. 1, p. 449 (1927).

39. Mayer, A. G. An Atlantic Palolo, Staurocephelus gregarius. Bull. Mus. Comp. Zool., Havard, Vol. 36, p. 1 (1900).

40. Mayer, A. G. The Atlantic Palolo, Eunice fucata. Sci. Bull. Mus., Brooklyn. Acad. Arts \& Science, Vol. 1, p. 93 (1902).

41. Mayer, A. G. The annual breeding swarm of the Atlantic Palolo. Carnegie Inst., Wash., Pub. No. 102, p. 107 (1908).

42. Moore, H. F. Volumetric studies of the food and feeding of oysters. Bull. Bureau Fish., Wash., Vol. 28, p. 1297 (1908).

43. Musset, C. Sélénetropisme des plantes. Compt. Rend. Acad. Sci., Paris, Vol. 96, p. 663 (1883), and Vol. 110, p. 201 (1890).

44. Orton, J. H. Sea-temperature, breeding and distribution in Marine Animals. Journ. Mar. Biol. Assoc., Vol. 12, p. 339 (1920).

45. Orton, J. H. An Account of Investigation into the cause or causes of unusual Mortality among oysters in English Oyster beds during 1920 and 1921. Fishery Invest. II, VI, No. 3 (1924). 
46. Orton, J. H. On Lunar Periodicity in Spawning of normally grown Falmouth Oysters $(O$. edulis) in 1925 with a comparison of the spawning capacity of normally grown and dumpy oysters. Journ. Mar. Biol. Assoc., Vol. 14, p. 199 (1926).

47. ORton, J. H. On the Rate of growth of Cardium edule. Journ. Mar. Biol. Assoc., Vol. 14, p. 239 (1926).

48. Orton, J. H., and Amirthalingam, C. Notes on Shell-deposition in Oysters. Journ. Mar. Biol. Assoc., Vol. 14, p. 935 (1927).

49. Pallary, P. Catalogue des Mollusques du littoral Méditerranéen de l'Égypte. La Caire (1912).

50. Patten, W. Eyes of Molluses and Arthropods. Mitth. Zool. Stat. Neapol., Vol. 6, p. 542 (1886).

51. Poole, H. H., and Atkins, W. R. G. On the Penetration of Light into Sea-water. Journ. Mar. Biol. Assoc., Vol. 14, p. 177 (1926-27).

52. Rowan, William. On Photoperiodism, Reproductive periodicity and the annual migration of Birds and certain Fishes. Proc. Boston Soc. Nat. Hist., Vol. 38, p. 147 (1926).

53: Savage, R. E. The Food of the Oyster. Fishery Invest., II, VIII, No. 1 (1925). London.

54. Sсотт, J. W. Egg-laying habits of Amphitrite ornata, Verrill. Biol. Bull., Vol. 17, p. 327 (1909).

55. Semmens, Elizabeth S. Hydrolysis of starch grains by light polarized by small particles. Nature, Vol. 117, p. 821 (1926), and Biol. Absts., Vol. 1, p. 449 (1927).

56. Strangeway, T. S. P., and Canti, R. G. The Living Cell in vitro as shown by Dark Ground illumination and the changes induced in such cells by fixing agents. Quar. Journ. Micro. Soc., Vol. 71, p. 1 (1927).

57. Tahara, M. On the periodical liberation of the oospheres in Sargassum. Bot. Mag., Tokyo., Vol. 23, p. 151 (1909).

58. Tennett, D. H. Variation in Echinoid plutei. Jour. Exp. Zool., Vol. 9, p. 657 (1910).

59. Thompson, W. F., and J. B. The swarming of the Grunion (Leuresthes tenuis). Cal. Fish. \& Game Com. Bull. No. 3 (1919).

60. Treadwell, A. L. On Eunice fucata. Carnegie Inst., Wash. Year Book, No. 8, p. 150 (1909). 
61. Treadwell, A. L. Leodicidæ of the West Indian Region. Dept. Mar. Biol., Carnegie Inst., Wash., Vol. 15, p. 1 (1921).

62. Whitmee, S. J. On the habits of Palolo viridis. Proc. Zoo. Soc., London, 1875, p. 496.

63. Williams, J. L. The periodicity of the sexual cells of Dictyota dichotoma. Ann. Bot., Vol. 19, p. 531 (1905).

64. Wright, F. E. Polarisation of light reflected from rough surfaces with special references to light reflected by the moon. Proc. National Acad. Sci., U.S.A., Vol. 13, p. 535 (1927).

65. Yoshir, Yoshyi. Some preliminary studies on the influence upon plants of the relative length of day and night. Sci. Rep. Tohokn. Imp. Univ., Vol. 2, p. 143 (1926), and Biol. Absts., Vol. 1, p. 447 (1927). 


\section{RECORDS}

Trawled on 9Th March, '27-Examined on 10Th and 11th. Bought from Quay.

The following conventions are used in the records :-

$$
\begin{aligned}
\mathrm{Cr} . & =\text { Creamy in colour. } & \mathrm{F} . & =\text { Full. } \\
\text { H.F. } & =\text { Half full. } & \text { R. } & =\text { Ripe }
\end{aligned}
$$

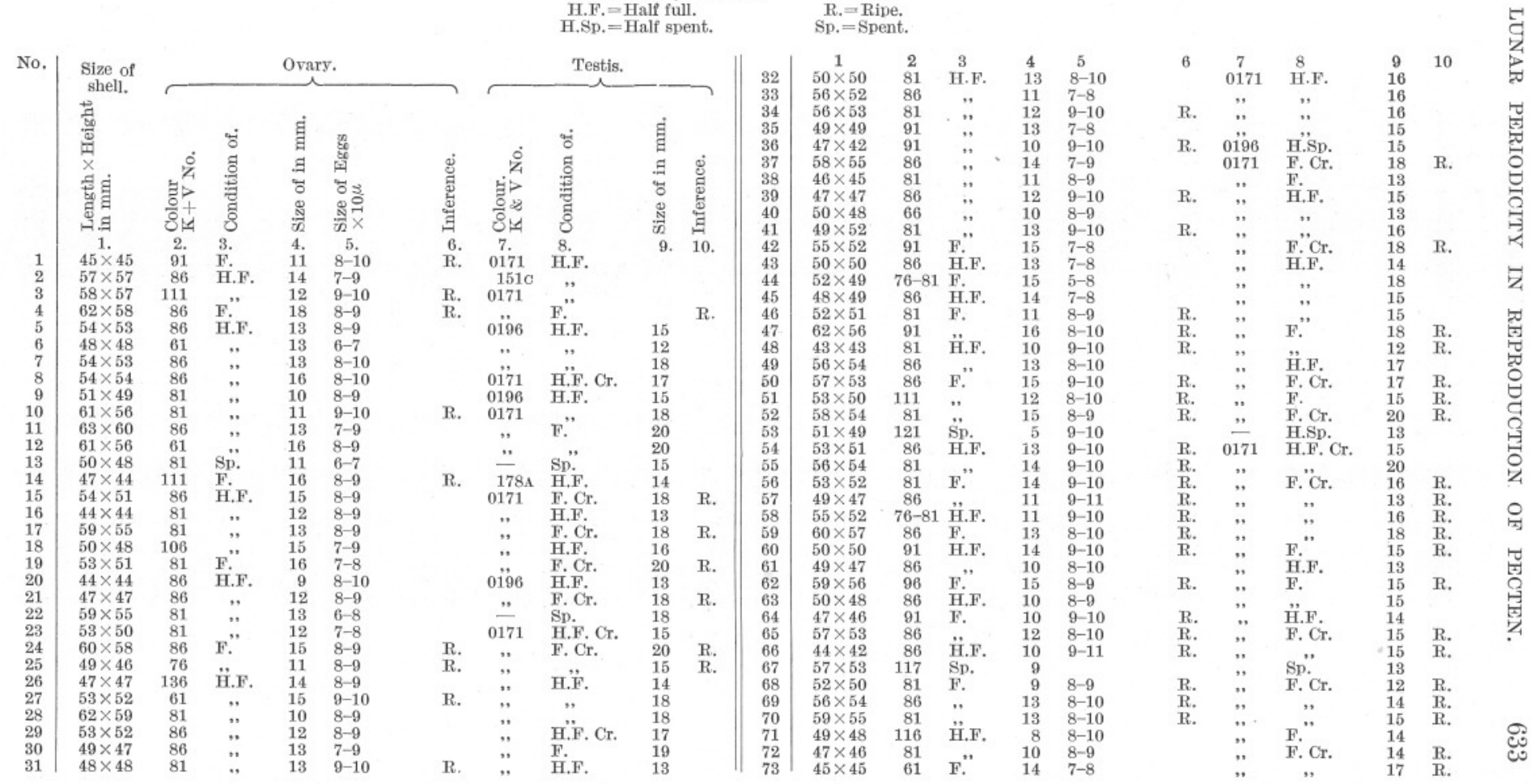



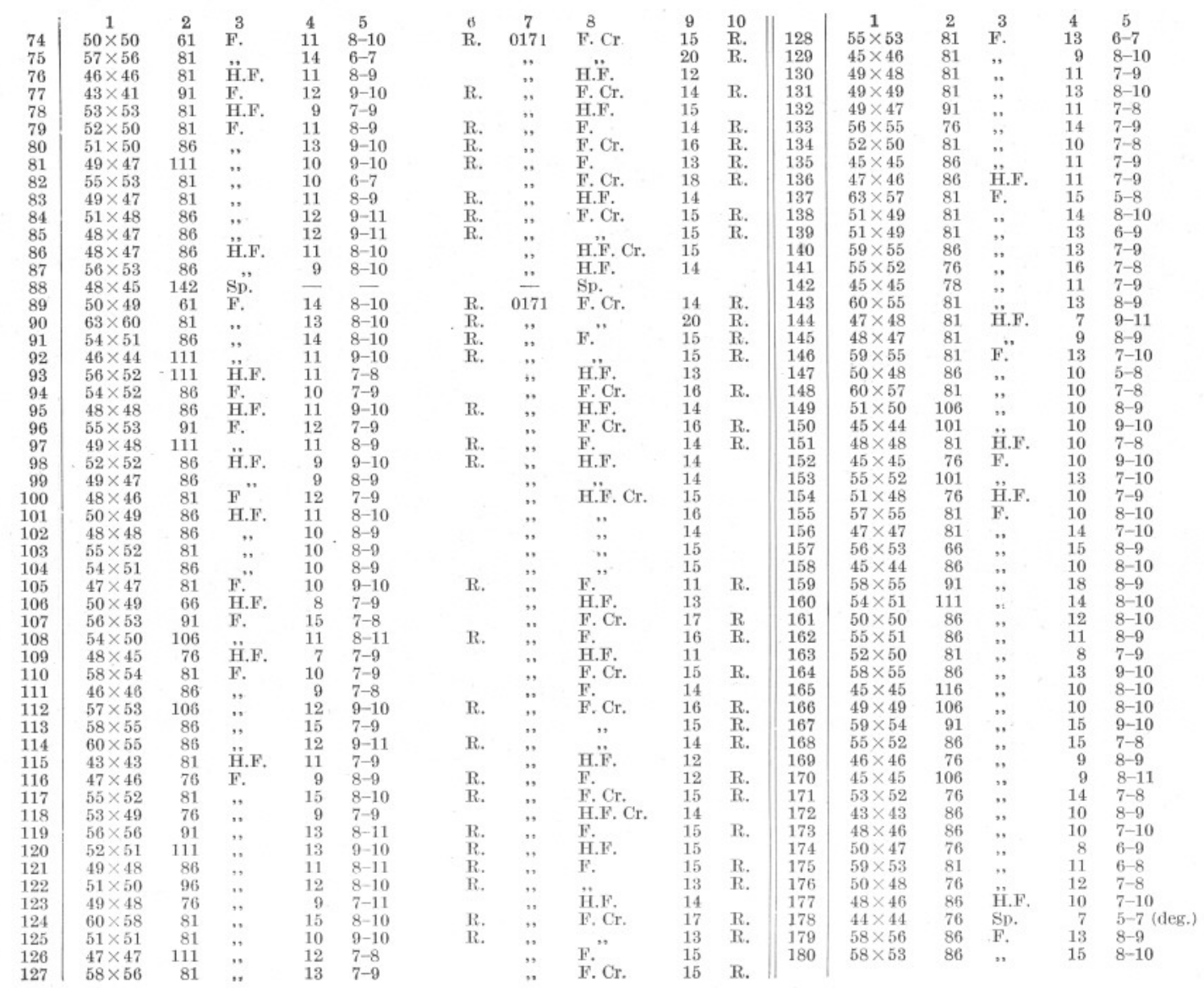

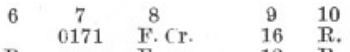

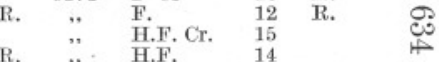
H.F.

R.

F."

Ḧ.F

(1)

R.
R.
R.

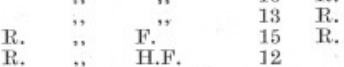

," H.F. Cr. 13

F. Cr. $\quad 16 \quad$ R.

$\begin{array}{llll}\text { R. } & \text { \#. Cr. } & 17 & \text { R. } \\ \text {. } & \text {. } & 14 & \text { R. }\end{array}$

R. .. н..". 12

R. $\quad$ F. Cr. 15 R.

H.F.

F. Cr.

F."

H.Sp.

H..

F. Cr.

$\begin{array}{ll}17 & \mathrm{R} . \\ 15 & \end{array}$

$\begin{array}{ll}5 & R . \\ 5 & R . \\ 5 & R .\end{array}$

$10 \mathrm{R}$

R.

$\begin{array}{ll}15 & \mathrm{R} \text {. } \\ 13 & \mathrm{R} .\end{array}$

$\begin{array}{lll}\text { R. } \quad, \quad \text { H.F. } & 12 \\ \text { F. } & 17\end{array}$

R. " F. Cr. $\quad 15 \quad$ R.

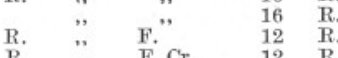

R. " F. Cr. 12 R.

R. " F. Cr

$\begin{array}{ll}10 & \mathrm{R} . \\ 12 & \mathrm{R} . \\ 15 & \end{array}$

$\begin{array}{lll}., & 12 & \mathrm{R} \\ . & 15 & \mathrm{R} .\end{array}$

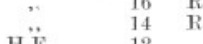

$\begin{array}{ll}\text { H.F. } & 12 \\ \text { Sp. } & 11 \\ & \end{array}$

$\begin{array}{ll}1 & \mathrm{R} \\ 7 & \mathrm{R}\end{array}$ 
Trawled on 13Th March, '27-Examined on 14th and 15Th. Bought from Quay.

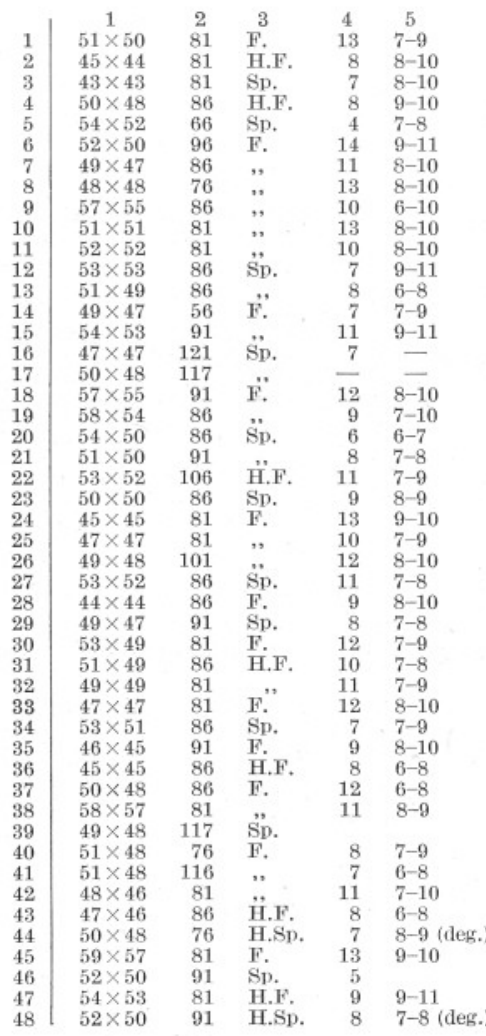

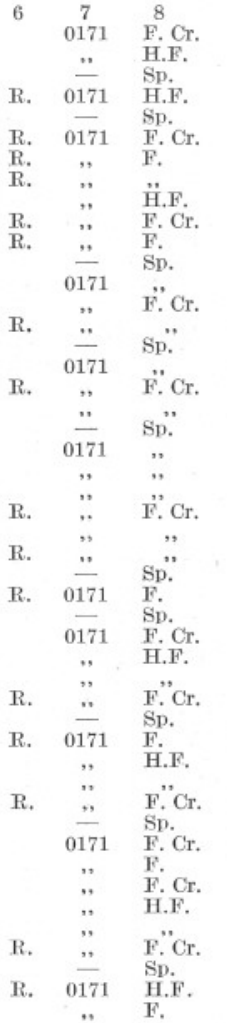
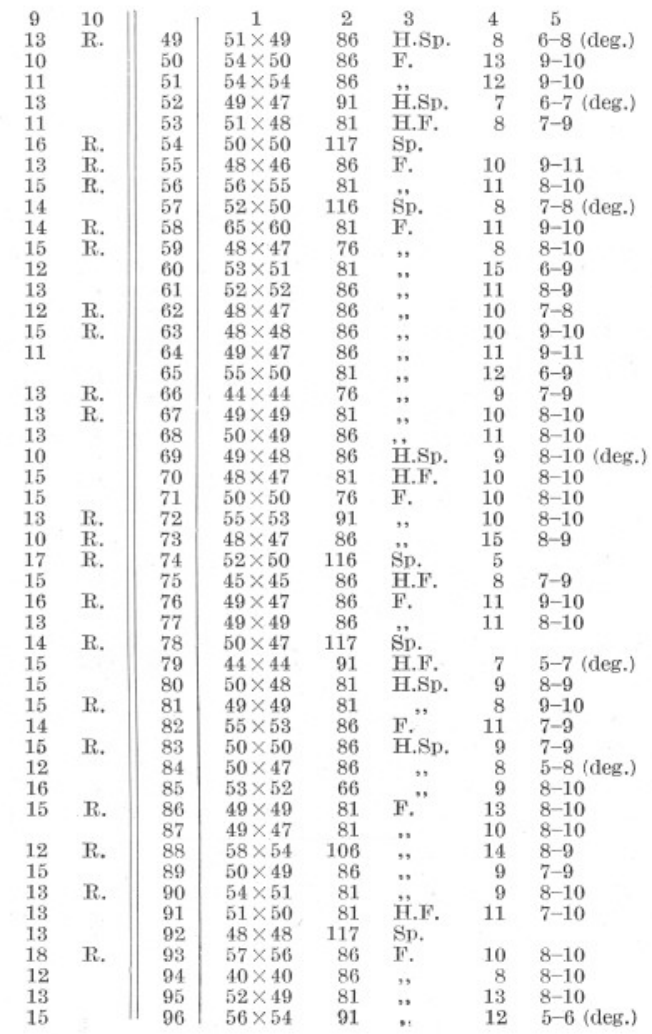

$\begin{array}{ccccc}6 & 7 & 8 & 9 & 10 \\ & 0171 & \text { H.F. } & 12 & \end{array}$

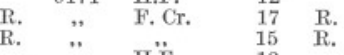

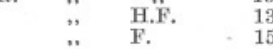

点

R. $\quad$ \#. F. Cr. $\quad 15$ R.

R. $\quad 0171$ H.F.

R. ," " "

$\mathrm{R}$.

H..̈.

R. " F. Cr. H.̈.

R. ", $\quad$ F. Cr.

R.

$12 \mathrm{R}$

0171 H.F.

F. 11

$\begin{array}{ll}\ddot{\bar{A}} & \text { Sp." } \\ 0171 & \text { H.F. }\end{array}$

$\begin{array}{ll}15 & \mathrm{R} . \\ 13 & \mathrm{R} .\end{array}$

0171 H.F. 12

" 14 12

$\begin{array}{ll}\text {," } & \text { F.Cr. } \\ \text { H.F. }\end{array}$

R.

R. " F"

16 च

R. "

н

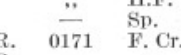

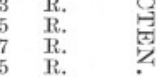

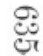




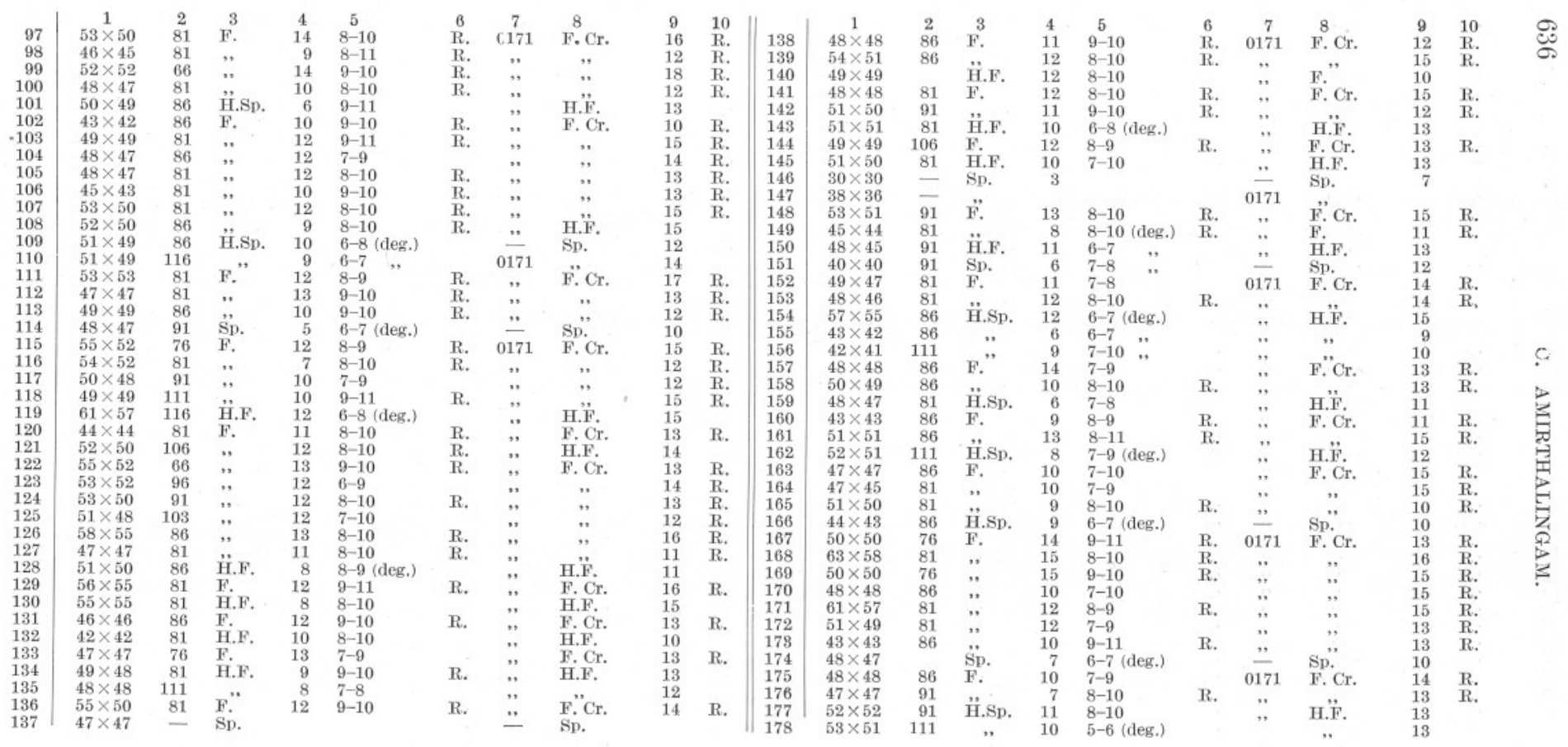


Trawled on 18Th March, '27-Examined on 19Th and 20Th. Bought from Quay.

Ring No.

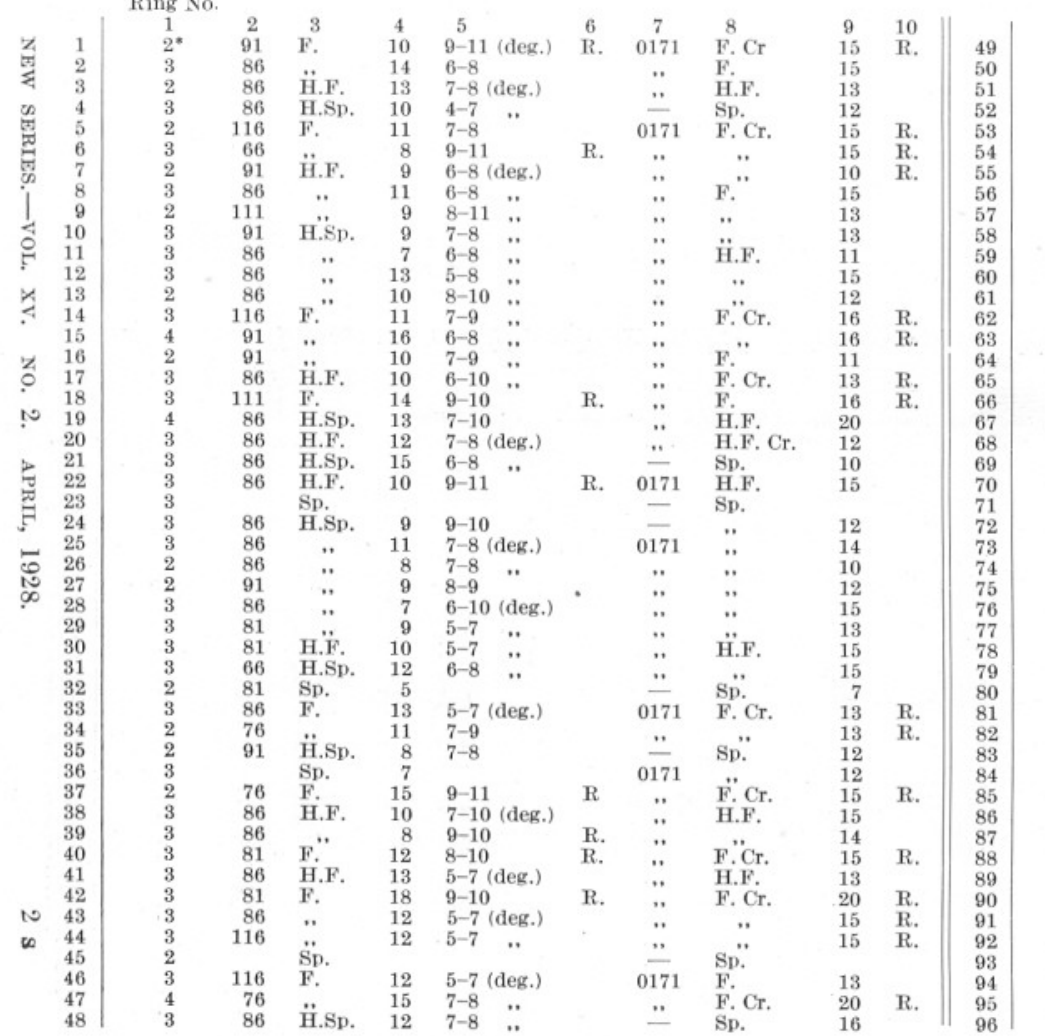

\begin{tabular}{|c|c|c|c|c|c|c|c|c|}
\hline 2 & 3 & & 5 & & & & 9 & 10 \\
\hline 81 & H.F. & 11 & $9-10$ & R. & 0171 & H.F. & $\begin{array}{l}8 \\
16\end{array}$ & 10 \\
\hline 86 & , & 14 & 5-7 (deg.) & & .. & F. Cr. & 15 & R. \\
\hline 86 & .. & 11 & $6-8$ & & .. & H.F. & 14 & \\
\hline 81 & ,. & 12 & $6-8$ & & ., & ., & 15 & \\
\hline 86 & .. & 12 & $7-8$ & & .. & .. & 17 & \\
\hline 81 & ., & 10 & 5-7 (deg.) & & .. & .. & 15 & \\
\hline 86 & .. & 14 & 6-7 & & .. & .. & 19 & \\
\hline 86 & ., & 11 & $7-9$ & & .. & .. & 16 & \\
\hline 86 & .. & 12 & $6-8$ & & .. & .. & 15 & \\
\hline 86 & .. & 14 & $6-9$ & & .. & .. & 14 & \\
\hline 86 & .. & 12 & 7-9 & & .. & .. & 15 & \\
\hline 86 & .. & 15 & $6-9$ & & .. & ,. & 15 & \\
\hline 86 & $"$. & 12 & $6-9$ & & .. & .. & 14 & \\
\hline 106 & F. & 12 & 7-9 & & .. & ... & 14 & \\
\hline 86 & ," & 10 & $6-8$ & & .. & ... & 14 & \\
\hline 86 & & 12 & $6-8$ & & .. & & 15 & \\
\hline & Sp. & 10 & & & & sp. & 15 & \\
\hline 86 & H.F. & 10 & $7-10$ & & 0171 & H.F. & 13 & \\
\hline 91 & F. & 9 & 7-9 (deg.) & & ., & F. & 10 & \\
\hline 86 & .. & 12 & $8-10$ & R. & .. & F. Cr. & 13 & R. \\
\hline 91 & $\ddot{\ddot{n}}$ & 9 & 6-10 (deg.) & & ". & H.F. & 12 & \\
\hline & Sp. & 8 & $5-6 \quad$, & & $\ddot{-}$ & Sp. & 12 & \\
\hline 86 & F. & 11 & $8-10$ & R. & 0171 & H.F. Cr. & 12 & \\
\hline 66 & , & 13 & 5-7 (deg.) & & .. & F. Cr. & 17 & \\
\hline 81 & & 15 & 6-8 $\quad$. & & .. &, & 18 & R. \\
\hline 116 & H.F. & 13 & $7-8 \quad .$. & & ... & ... & 16 & R. \\
\hline 86 & .. & 12 & $6-9$ & & ".. & н. & 13 & \\
\hline 81 & ,, & 13 & $8-10$ & & ... & & 17 & \\
\hline 86 & .. & 12 & $7-9$ & & ". & H.F. Cr. & 16 & \\
\hline 66 & ., & 13 & $7-9$ & & ,." & & 13 & \\
\hline 76 & $\because$ & 12 & $7-9$ & & .. & H. $\ddot{\text {. }}$ & 13 & \\
\hline 86 &.. & 10 & 5-8 (deg.) & &.. & . & 14 & \\
\hline 111 & ,. & 11 & $7-9$ & & ". & ... & 13 & \\
\hline 86 & .. & 11 & 5-7 (deg.) & & ... & .. & 10 & \\
\hline 86 & ,, & 13 & $5-7 \quad$. & & ".. & $\ddot{~}$ & 15 & \\
\hline 86 & .. & 11 & $6-8 \quad .$. & & ".. & H.F. Cr. & 13 & \\
\hline 86 & $\because$ & 11 & $4-8 \quad$. & &.. & & 14 & \\
\hline 76 & ". & 11 & $6-8 \quad "$ & & .. & Н..̈.' & 14 & \\
\hline 106 &.. & 10 & $7-9$ & & .. & H.F. Cr. & 14 & \\
\hline 76 & ,. & 11 & $7-9$ & & ,. & & 15 & \\
\hline 76 & & 9 & 5-7 (deg.) & & ... & H. $\ddot{F}$. & 12 & \\
\hline 86 & H.Sp. & 9 & $7-9 \quad$. & & $\ddot{-}$ & Sp. & 13 & \\
\hline 81 & F. & 12 & 7-9 & & 0171 & H.F. & 17 & \\
\hline 96 & & 14 & $6-10 \quad .$. & & , & F. Cr. & 15 & R. \\
\hline 76 & H.F. & 11 & 6-8 & & ". & H.F. & 13 & \\
\hline 81 & , & 10 & $6-9$ & & .. & & 13 & \\
\hline 86 & ,. & 11 & $8-10$ & & .. & H.F. Cr. & 15 & \\
\hline 76 & .. & 11 & $8-10$ & & .. & H.F. & 16 & \\
\hline
\end{tabular}




\begin{tabular}{|c|c|c|c|c|c|c|}
\hline 2 & 3 & 4 & 5 & 6 & 7 & \\
\hline 116 & H.F. & 13 & $5-9$ (deg.) & & 0171 & H.F. Cr. \\
\hline & . & 10 & $7-9$ & & " & \\
\hline 91 & $\therefore$ & 12 & $7-10$ & & " & \\
\hline & ". & 10 & 7-9 & & .. & H.F. \\
\hline & , & 12 & 7-9 & & .. & , \\
\hline & , & 10 & $6-8$ & & .. & ." \\
\hline 91 & ,. & 10 & 7-9 & & " & , \\
\hline 86 & sü & 12 & $7-9$ & & $\ddot{ }$ & $s \ddot{p}$ \\
\hline 86 & H.F. & 15 & $6-8$ & & 0171 & H.F. Cr. \\
\hline 86 & H.F. & 13 & $6-7$ & & 0171 & H.F. \\
\hline 86 & F. & 11 & $7-8$ & & , & \\
\hline 76 & H.F. & 11 & $6-8$ & & .* & H.F. \\
\hline 86 & & 11 & $7-8$ & & ". & ", \\
\hline 76 & H.Sp. & 9 & $8-9$ & & 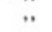 &. \\
\hline 86 & & 13 & 6-7 (deg.) & & ". & ," \\
\hline 76 & H.F. & 13 & 6-7 $\quad$, & & .. & ", \\
\hline 91 & .. & 14 & $7-9$ & & , & ,, \\
\hline 96 & $"$ & 12 & 6-8 & - & ". & $\mathrm{Fr}$ \\
\hline $\begin{array}{l}76 \\
76\end{array}$ & H.F. & $\begin{array}{l}13 \\
16\end{array}$ & $\begin{array}{l}6-8 \\
7-10\end{array}$ & & .. & $\begin{array}{l}\text { F. Cr. } \\
\text { H.F. }\end{array}$ \\
\hline 81 & & 15 & $8-10$ & R. & ,. & F. Cr. \\
\hline 81 & H.F. & 14 & 6-7 (deg.) & & .. & H.F. \\
\hline 71 & 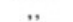 & 15 & $6-8$ & & .. & .. \\
\hline 81 & . & 9 & 6-8 (deg) & & " & ," \\
\hline 76 & .. & 15 & $7-8 \quad$, & & ., & , \\
\hline
\end{tabular}
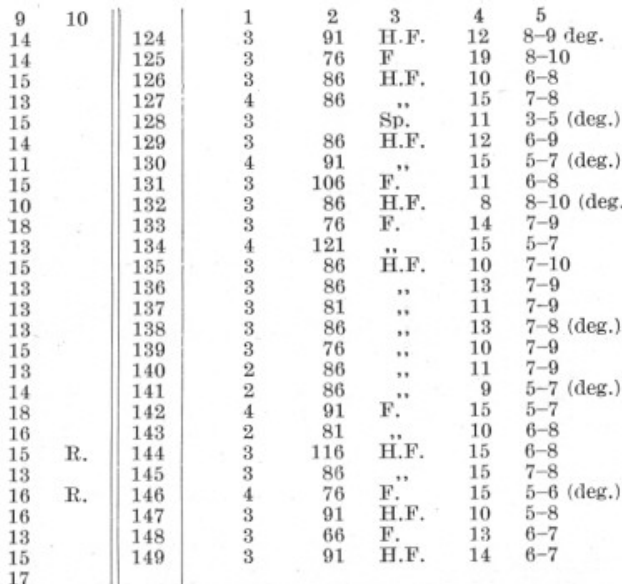

$\begin{array}{ccc}\text { B } & 7 & 8 \\ \text { R. } & 0171 & \text { H.F. } \\ & \text { H. } & \text { F. Cr. }\end{array}$

$\begin{array}{rr}9 & 10 \\ 13 & \end{array}$

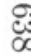

Ring No. $1=30-40 \mathrm{~mm}$.; Ring No. $2=40-50 \mathrm{~mm}$. : Ring No. $3=50-60 \mathrm{~mm}$.; Ring No. $4=60-70 \mathrm{~mm}$

Trawled on 23rd March, '27-Examined on 24th and 25th. Bought From Quay.

\begin{tabular}{r|l} 
& 1 \\
1 & 4 \\
2 & 4 \\
3 & 2 \\
4 & 3 \\
5 & 3 \\
6 & 3 \\
7 & 3 \\
8 & 3 \\
9 & 4 \\
10 & 3 \\
11 & 3 \\
12 & 4 \\
13 & 3 \\
14 & 3 \\
15 & 4 \\
16 & 3
\end{tabular}

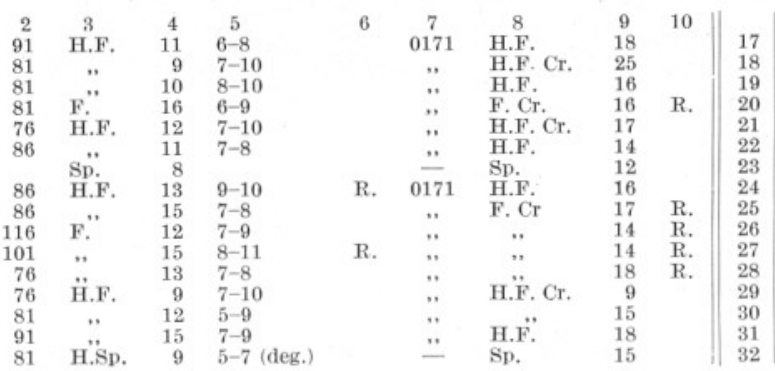

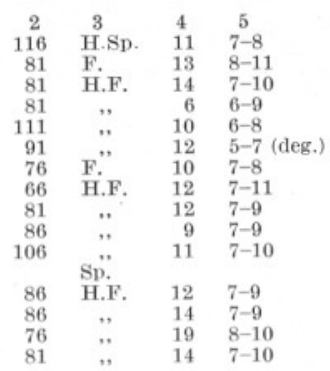

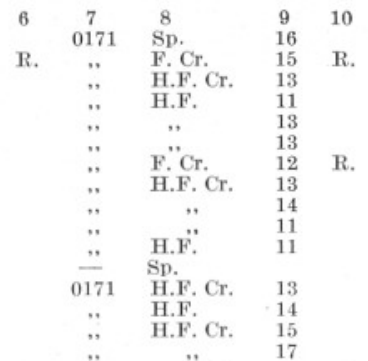



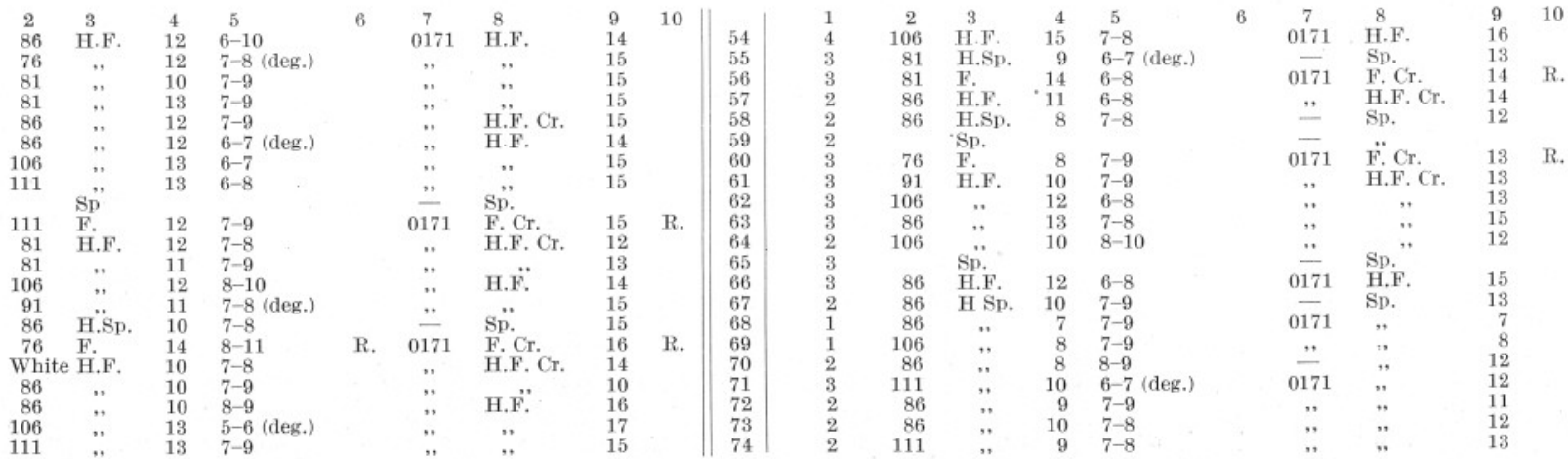

Trawled on 29Th M̀reh, '27-Examined on 30Th and 31st. Bought from Quay.
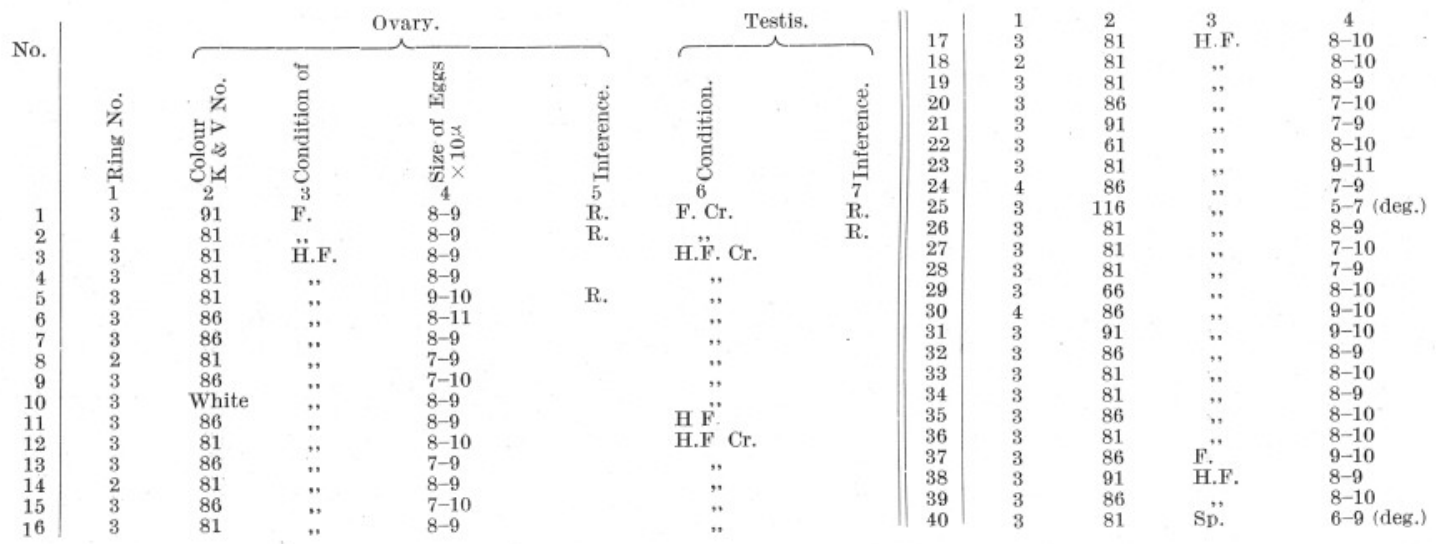

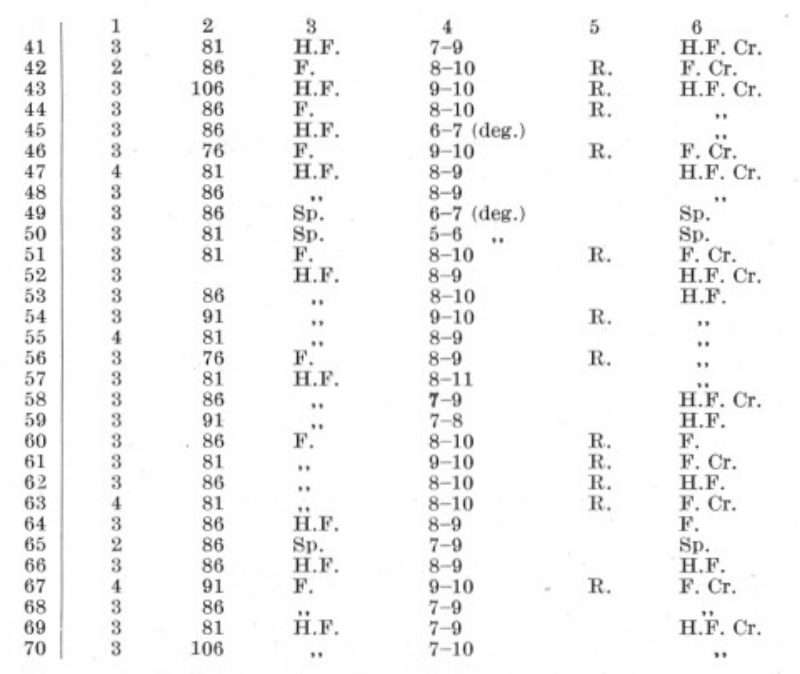

\begin{tabular}{l||r||}
7 & \\
71 \\
R. & 72 \\
& 73 \\
& 74 \\
& 75 \\
R. & 76 \\
& 77 \\
& 78 \\
& 79 \\
R. & 80 \\
& 81 \\
& 83 \\
& 84 \\
& 85 \\
& 86 \\
& 87 \\
R. & 88 \\
R. & 90 \\
R. & 91 \\
& 92 \\
& 93 \\
R. & 95 \\
R. & 96 \\
& 97 \\
& 99 \\
& 100
\end{tabular} \mid
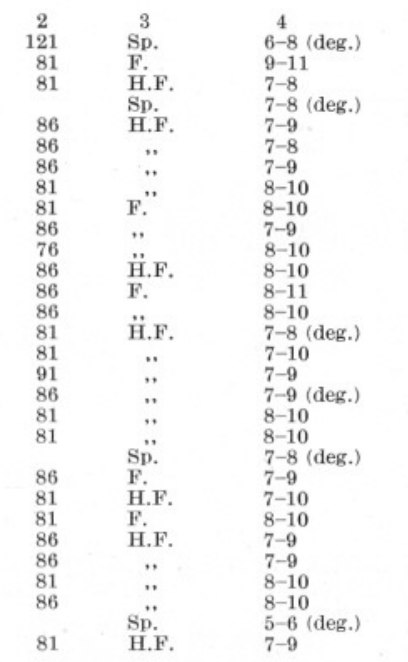

6
Sp.
F. Cr.

옹

Trawled on 7th April, '27-Examined on 8Th. Bought from Quay.
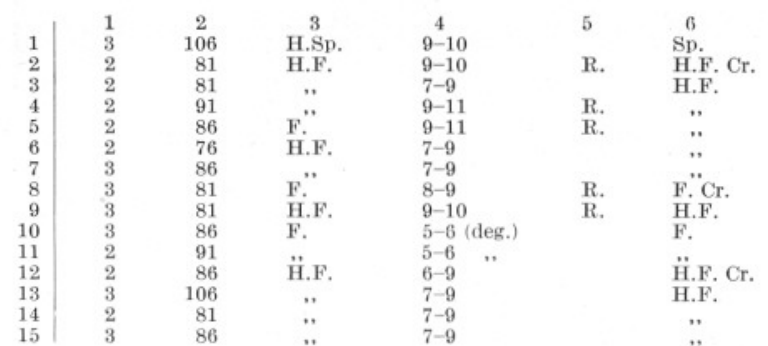

$\begin{array}{rlc}2 & 3 & 3 \\ 86 & \text { H.F. } & 7-9 \\ 81 & \text { F." } & 7-8 \\ 86 & 9-10 \\ 81 & \text {.̈.F. } & 10-11 \\ 81 & 7-9 \\ 106 & \text { F. } & 9-11 \\ 86 & \text { H.F. } & 7-9 \\ 81 & 7-8 \\ 71 & \text {.. } & 8-9 \\ 76 & \text { F. } & 7-8 \\ 86 & 7-9 \\ 81 & \text {.. } & 8-9 \\ 86 & \text {. } & 7-8 \\ 106 & \text { H.F. } & 8-9 \\ 86 & 7-9\end{array}$

\begin{tabular}{lll}
5 & \multicolumn{1}{c}{6} & 7 \\
& H.F. & \\
R. & F."Cr. & R. \\
R. & F. & R. \\
R. & H.F. & R. \\
& F. & R. \\
& H.F. & \\
& F." & R. \\
R. & F." & R. \\
R. & F. Cr. & R. \\
H.F. & R.
\end{tabular}




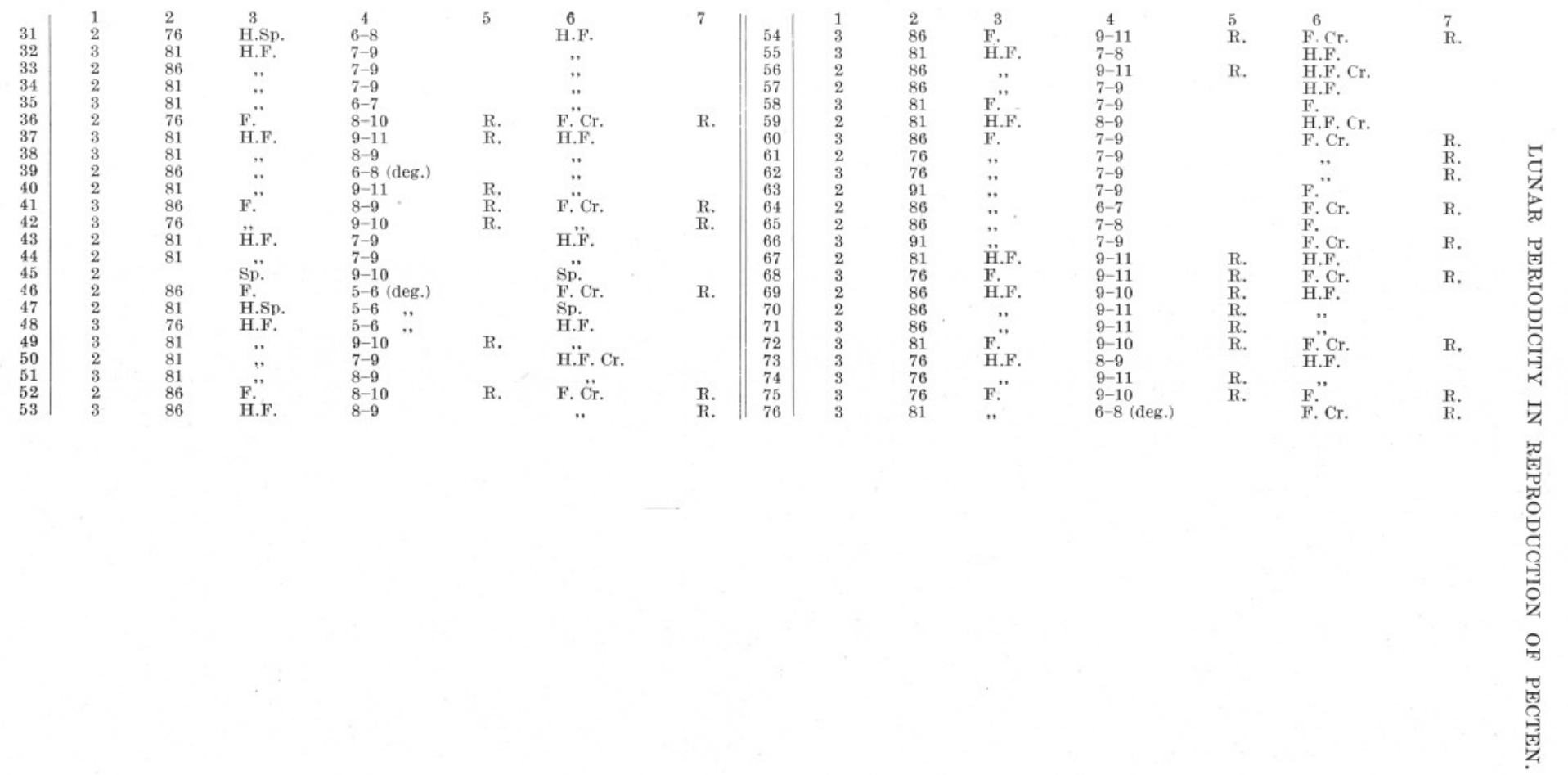


